\title{
Sociale betekenis en taalvariatie in luisterverhalen voor Vlaamse kinderen
}

\section{Catho Jacobs, Stefania Marzo en Eline Zenner}

\begin{abstract}
The field of sociolinguistics recently witnessed an upsurge of studies that investigate the way and period in which children acquire the social meaning of language, and that scrutinize the role of input for that acquisition. Language variation is at the same time increasingly studied in fictional genres, which have long been ignored because of the sociolinguistic emphasis on 'authentic' language use. Both areas are brought together in this study, which looks into children's exposure to language variation in Flemish child-directed media. Through a corpus analysis of the language use and the social characteristics of 260 characters from 12 audio plays for (Flemish) children, we address three research questions: (RQ1) how diverse is the language repertoire to which children are exposed in Flemish audio plays?; (RQ2) how can we categorize the language use of the characters in the audio plays while taking into account the diaglossic continuum of varieties in the Flemish linguistic landscape?; (RQ3) which social characteristics are indexed by the varieties in the audio plays? The results show that (i) the Flemish diaglossic language repertoire is reflected in the classification of the language use of the characters; (ii) Colloquial Belgian Dutch and the Belgian Dutch standard language serve as reference varieties in the corpus; (iii) the Belgian Dutch standard language is most typically associated with prestige, whereas West-Flemish and French have a notably more diverse social meaning potential.
\end{abstract}

Keywords language variation, social media, fiction, audio plays, child-directed media

\section{De gebruiksgebaseerde verwerving van sociale betekenis: een blik op kindgerichte media}

De sociale betekenis van taalvarianten en -variëteiten omvat alle sociale attributen die met die taalvariant of -variëteit en zijn gebruikers geassocieerd worden (Walker et al. 2014). Voorliggende studie kruist twee recente perspectieven op deze sociale betekenis in de sociolinguïstiek: (i) onderzoek naar de verwerving van de sociale betekenis van taal en (ii) de studie van 'cinematografisch', fictioneel taalgebruik. Het eerste domein, de zogenaamde 'ontwikkelingssociolinguïstiek', betreft de studie naar de manier waarop en de periode waarin kinderen de in hun gemeenschap heersende normen inzake taalvariatie, register en stijl verwerven, samen met hun bijhorende sociale betekenis (zie Smith et al. 2007, Miller 2013, en zie De Vogelaer \& Katerbow 2017 voor een brede inleiding). Met aandacht voor de typische macrosociale variabelen leeftijd, geslacht, en sociale klasse, brengen onderzoekers in kaart hoe kinderen beschikbare sociolinguïstische variabelen en variëteiten (met stip standaard- en vernacular 'omgangstaal') leren inzetten op een manier die de volwassen patronen weerspiegelt (Ghimenton et al. 2013). In dit verband wordt vaak aandacht gespendeerd aan de rol van de input die kinderen via hun primaire verzorgers ontvangen. Terugkerende patronen van variatie in kindgericht taalgebruik omvatten hierbij onder andere (i) meer standaardtaal in kindgericht taalgebruik dan in taalgebruik tussen volwassenen onderling; (ii) meer omgangstaal naarmate kinderen ouder worden; (iii) meer omgangstaal tegen jongens dan tegen meisjes; (iv) meer standaardtaal bij moeder dan bij vader (Roberts \& Labov 1995, Kerswill \& Williams 2000, Foulkes \& Docherty 2005, Smith et al. 2007, 2013, Smith \& Durham 2019, Chevrot et al. 2011). Studies in Vlaamse context zijn in dit verband het onderzoek van De Houwer (2003) naar dialectvormen in kindgericht taalgebruik en het onderzoek naar tussentaal-standaardtaalvariatie in Van De Mieroop et al. (2016). 
Het kindgericht taalgebruik van de primaire verzorgers is de meest bestudeerde, maar natuurlijk niet de enige bron van taalinput voor (jonge) kinderen. Zoals uit de bekende studie van Lippi-Green (1997) naar het taalgebruik van personages uit Disneyfilms bleek, worden kinderen ook via de media aan een specifiek taalrepertoire blootgesteld, waarbij terugkerende koppelingen tussen taal en sociale betekenis kunnen worden opgetekend. Hoewel de precieze bijdrage van media aan taalverandering nog voorwerp is van intens taalkundig debat (Tagliamonte 2014), lijkt alvast duidelijk dat sociolinguïstische keuzes net als in de maatschappij zelf ook in fictie begrensd worden door 'audience design at the level of target audiences' (Androutsopoulos 2012a op basis van Bednarek 2010, Richardson 2010). Onderzoek naar 'cinematografisch taalgebruik' benadrukt verder dat taalgebruik in fictie niet zomaar kan worden bestudeerd als weinig authentieke weerspiegeling van de talige realiteit, maar op zichzelf (talige en sociale) realiteit construeert in de fictionele sociale context (Androutsopoulos 2012a: 143-144, en zie Van Hoof 2013: 27). Hoe die constructie van de sociale realiteit via taal precies verloopt in fictie voor een jong doelpubliek is, zeker in Vlaamse context, nog weinig bestudeerd. Hoewel al enkele studies hun pijlen richtten op taalvariatie in de Vlaamse media (Geeraerts et al. 2000, Van Hoof 2013 - ook voor een overzicht, Van Hoof 2015), bestudeerden bij ons weten enkel De Wachter \& Heeren (2010) en Žárská (2019) kindgerichte media. Waar De Wachter \& Heeren (2010) de verschillen nagaan in het taalgebruik van 27 personages van de Nederlandse en Vlaamse versies van drie oorspronkelijk Engelstalige animatiefilms, bekijkt Žárská de accenten en variëteiten aanwezig in de gedubde versie van de film Harry Potter and the Prisoner of Azkaban, met specifieke aandacht voor de vertaling van regionale variëteiten van het Engels. In beide gevallen betreft de studie oorspronkelijk Engelstalige media die worden vertaald voor een Nederlandstalig publiek.

In deze studie vestigen we de aandacht op de constructie van de sociale betekenis van taal in kindgerichte fictie van een oorspronkelijk Vlaams productiehuis, namelijk de Heerlijke Hoorspelen van het Geluidshuis. De hoorspelen, waar door het gebrek aan visuele input taalvariatie een nog prominentere rol kan spelen voor stilering en karaktertekening, worden vanuit twee perspectieven geanalyseerd. Ten eerste willen we nagaan aan welk taalrepertoire de jonge ontvangers van de hoorspelen worden blootgesteld: hoe uitgebreid is het aanbod aan variëteiten en accenten dat kinderen te horen krijgen in de hoorspelen, met welke frequentie treffen we elk van die aangeboden variëteiten en accenten aan, en valt hier een asymmetrie vast te stellen waarbij een of meerdere van de beschikbare variëteiten de functie van referentievariëteit inneemt? ${ }^{1}$ Ten tweede willen we in kaart brengen of bepaalde variëteiten of accenten typisch met bepaalde sociale eigenschappen van personages in verband gebracht worden. Beide onderzoeksperspectieven worden hieronder kort verder toegelicht.

De formulering van het eerste onderzoeksperspectief naar het aangetroffen taalrepertoire in de hoorspelen bevat de assumptie dat het taalgebruik van de personages in de audioboeken in te delen is in aflijnbare variëteiten. Die assumptie is echter, zeker in Vlaamse context, niet onproblematisch. Vanuit de typologie van Auer $(2005,2011)$ kan het Vlaamse taalrepertoire omschreven worden als diaglossisch: tussen de Vlaamse dialecten (typisch onderscheiden in vier groepen: Brabants, OostVlaams, Limburgs en West-Vlaams, zie bv. Devos \& Vandekerckhove 2005) en de Belgisch-Nederlandse standaardtaal in bevindt zich een continuüm aan intermediaire vormen (zie Ghyselen 2016), waarbij het niet altijd vanzelfsprekend is scherpe grenzen te trekken tussen de verschillende lagen van het taalrepertorium (zie Ghyselen \& De Vogelaer 2018 voor een theoretische toelichting bij de complexiteit van het concept 'variëteit'). Een bijkomende moeilijkheid betreft intrasprekervariatie. Ondanks het soms vermeende monostylisme van fictieve personages (zie Mesthrie 2005) wisselen ook

\footnotetext{
${ }^{1}$ Hiermee bedoelen we de default-variëteit die de standaardkeuze is voor personages.
} 
fictieve personages tussen varianten en variëteiten (zie Androutsopoulos 2012b). Ook in Vlaamse context werden dergelijke style-shifts bij fictionele personages aangetoond (Žárská 2019). Hoewel we er in deze studie in navolging van Lippi-Green (1997) voor opteren om de nadruk te leggen op intersprekervariatie, besteden we expliciet aandacht aan het methodologische vraagstuk van de categorisering van het taalgebruik van de personages in de luisterverhalen tegen de achtergrond van het diaglossische continuüm van variëteiten in het Vlaamse taallandschap (zie Sectie 2.2).

Het tweede onderzoeksperspectief, dat zich richt op terugkerende koppelingen tussen taalvariëteiten en accenten met sociale betekenis, baseert zich op Androutsopoulos (2012a: 145), die stelt dat taalgebruik in fictie opvallend gevoelig is voor stereotypering, 'by which reduced linguistic variability is tied to generalised social categories, producing crude and undifferentiated images of how certain social types use language'. Dergelijke stileringen (Coupland 2007) faciliteren de herkenning door de ontvanger van het stereotype beeld dat de zender wil creëren, waarbij 'makers van fictie putten uit hun kennis van de manier waarop mensen in het dagelijkse leven hun conversaties vormgeven, en ze rekenen erop dat hun publiek hetzelfde doet bij de interpretatie van fictiedialogen' (Van Hoof 2013: 36 over Bubel 2008 en Stokoe 2008, Culpeper 2001), om zo de karaktertekening van hun personages te verscherpen. Bij kinderen kan echter niet op dezelfde vanzelfsprekende manier worden uitgegaan van de herkenning van stereotiepe koppelingen tussen taal en sociale betekenis. Een eerste vraag is dan in welke mate stemacteurs en scriptschrijvers (toch) inspelen op gangbare koppelingen tussen talige en sociale kenmerken. Indien de zender dergelijke in de maatschappij stereotiepe koppelingen maakt en aanbiedt aan het jonge doelpubliek, dan bewerkstelligt en/of versterkt de zender net de registratie van die koppeling bij het publiek. Zo worden de media een bron van input die kinderen helpt om de sociale betekenissen die een variant, variëteit of accent heeft of kan hebben aan te leren. Dat proces werd voor kinderen nog niet scherp in kaart gebracht (zeker niet in Vlaamse context), maar werd bij volwassenen als volgt beschreven:

Media zijn m.a.w. systemen die een significante rol kunnen spelen in processen van enregisterment (Agha 2003): ze dragen bij tot zowel de reproductie als de contestatie of de meer geleidelijke verandering van in de samenleving gangbare ideologische betekenissen van taalvariëteiten, oefenen een invloed uit op de attitudes die in de samenleving tegenover die variëteiten gekoesterd worden, en zijn mee bepalend voor de distributie van taalvormen in verschillende contexten (Coupland 2007: 185; StuartSmith 2011: 225). (van Hoof 2013: 42).

De manier waarop in de samenleving gangbare betekenissen van taalvariëteiten en accenten aangeboden worden aan een jong doelpubliek in hoorspelen van een Vlaams mediahuis, vormt het voorwerp van deze studie. Samengevat zoeken we daarbij een antwoord op de volgende drie onderzoeksvragen, waarbij het beantwoorden van onderzoeksvraag (2) als methodologische voorwaarde dient voor onderzoeksvraag (1):

1) Hoe divers is het taalrepertoire waaraan kinderen worden blootgesteld in Vlaamse luisterverhalen?

a. Hoe uitgebreid is het 'repertoire' (Androutsopoulos 2012b) aan variëteiten en accenten dat kinderen te horen krijgen in de hoorspelen?

b. Met welke frequentie komen elk van de aangeboden variëteiten en accenten aan bod?

c. Valt een asymmetrie vast te stellen waarbij een of meerdere van de beschikbare variëteiten de functie van referentievariëteit inneemt?

2) Hoe kan het taalgebruik van de personages in de luisterverhalen gecategoriseerd worden, rekening houdend met het diaglossische continuüm van het Vlaamse taalrepertoire? 
3) Welke sociale eigenschappen van de personages worden door de variëteiten in de hoorspelen (terugkerend) geïndexeerd?

De drie onderzoeksvragen worden behandeld aan de hand van een corpusgebaseerde studie waarin het taalgebruik en de sociale eigenschappen van 260 personages uit 12 hoorspelen voor kinderen worden geanalyseerd. Sectie 2 beschrijft de methode van ons onderzoek in meer detail, waarna in Sectie 3 de resultaten worden voorgesteld. Tot slot biedt Sectie 4 een discussie en conclusie.

\section{Methode}

De methode van dit corpusonderzoek kan in drie stappen worden opgedeeld. Om de onderzoeksvragen aan te pakken is het immers nodig om (1) een corpus aan te leggen van luisterverhalen en de personages die in deze luisterverhalen aan bod komen te inventariseren (Sectie 2.1); (2) het taalgebruik van de personages in de luisterverhalen te categoriseren met aandacht voor de diaglossische taalsituatie in Vlaanderen (Sectie 2.2); (3) in kaart te brengen welke sociale eigenschappen de personages bezitten (zie Sectie 2.3).

\subsection{Corpus}

Het corpus voor deze studie bestaat uit de eerste twaalf Heerlijke Hoorspelen van Het Geluidshuis. Deze luisterverhalen zijn uitgegeven tussen 2007 en 2016, en zijn expliciet gericht op lagereschoolkinderen. Hieruit werd een inventaris afgeleid van de 542 personages die aanwezig zijn in de audioboeken. Om een werkbare dataset te verkrijgen werden de volgende groepen personages verwijderd: ${ }^{2}$

(1) personages die slechts weinig zeggen, en daardoor te kort aan het woord zijn om de variëteit of het accent te bepalen ( $n=158)$;

(2) personages waarvan de variëteit of het accent moeilijk te bepalen is doordat ze onduidelijk spreken omdat ze lispelen, heel snel, traag, hoog of laag spreken, een vreemde klemtoon hanteren of hoestend, grommend of blatend spreken $(n=81) ;{ }^{3}$

(3) bekende personen die als zichzelf opduiken (bijvoorbeeld Jan Becaus of Erik Van Looy in 'De Reisgenoot'), aangezien de variëteiten of accenten die deze personen gebruiken in zekere zin buiten de fictieve context vallen $(n=16)$;

(4) personages die een vreemde taal spreken ( $n=14)$;

(5) personages die enkel zingen $(n=12)$, omdat de overschakeling van spraak naar zang in de luisterverhalen typisch gepaard gaat met een style-shift; in deze analyse richten we ons enkel op de variëteit of het accent van de personages in interactie;

(6) de verteller, die vertolkt wordt door Warre Borgmans, aangezien het een overkoepelend personage is dat buiten de eigenlijke verhaallijn van de luisterverhalen staat $(n=1)$.

De uiteindelijke dataset bestaat zo uit 260 personages. Vervolgens worden het taalgebruik en de sociale kenmerken van de personages gecategoriseerd (vergelijk Androutsopoulos 2012b). Dit wordt in de volgende secties in meer detail besproken. De resulterende dataset is terug te vinden als supplement B.

\footnotetext{
${ }^{2}$ Hoewel we deze personages verwijderd hebben uit het huidig corpus, zouden ze op zichzelf erg interessant kunnen zijn voor sociolinguïstische analyse. Ze vallen echter buiten het bestek van de huidige studie omdat we hier een veeleer zuivere kijk op variëteiten en accenten nastreven.

${ }^{3}$ Merk op dat verder onderzoek zou kunnen nagaan hoe net deze eigenschappen op zichzelf worden ingezet om sociale betekenis te construeren, al dan niet in samenspel met het gebruik van bepaalde variëteiten of accenten. Dit valt echter buiten het bestek van voorliggend onderzoek.
} 


\subsection{Gehanteerde variëteiten en accenten}

Deze studie wil het repertoire aan taalvariëteiten en accenten in kaart brengen waaraan kinderen worden blootgesteld in de Vlaamse hoorspelen van Het Geluidshuis. Hiertoe ondernemen we in eerste instantie een poging om het taalgebruik van de personages in ons corpus te categoriseren. Zoals hierboven al werd aangegeven, vertrekken we hierbij net als De Wachter \& Heeren (2010) en LippiGreen (1997) vanuit het niveau van het personage, waarbij we op zoek gaan naar een geschikt label voor het taalgebruik van dat personage. Zoals in de inleiding werd geschetst, wordt dergelijke afgelijnde categorisering per personage bemoeilijkt door twee factoren: (1) het diaglossische karakter van de Vlaamse taalsituatie, waarbij verschillende variëteiten in elkaar overvloeien veeleer dan strikt van elkaar af te scheiden zijn; (2) het optreden van style-shifts, waarbij een personage binnen en tussen uitingen wisselt tussen varianten, variëteiten en accenten (Androutsopoulos 2012b). Tegelijk verwachten we binnen de fictieve context van de hoorspelen dat toch minstens een deel van de personages net wel een duidelijk herkenbare hoofdvariëteit of -accent hanteert, ongeacht occasionele style-shifts. Het proces van stilering dat in de inleiding werd beschreven, gaat immers net uit van het aanbieden van duidelijke (talige en sociale) stereotypen die door de ontvanger vlot als dusdanig herkend kunnen worden. Deze assumpties worden empirisch geverifieerd volgens de methode die we hieronder toelichten.

Waar De Wachter \& Heeren (2010) voor de categorisering van het taalgebruik per personage gebruikmaken van een taalkundige analyse van taalvarianten aanwezig in steekproeven van uitingen per personage, ligt onze focus op de perceptie van geschoolde taalkundigen van het taalgebruik in steekproeven. Schmidt (2005) en Lenz (2010) benadrukken immers dat het identificeren van een variëteit niet enkel afhangt van de aanwezigheid van een bundel covariërende taalvarianten, maar eveneens gelieerd is aan wat door taalgebruikers als taalvariëteit wordt herkend (zie Grondelaers et al. 2011 en Ghyselen \& De Vogelaer 2018 voor een uitgebreide bespreking).

Concreet maakten we in dit onderzoek gebruik van de oordelen van vier opgeleide taalkundigen, een per dialectgebied in Vlaanderen (West-Vlaams, Oost-Vlaams, Brabants en Limburgs; zie Ghyselen \& De Vogelaer 2018: 6). De beoordelaars kregen voor elk van de 260 personages een fragment te horen van ongeveer twintig seconden lang dat representatief is voor de algemene spraak van het personage in het luisterverhaal. Mogelijke style-shifts doorheen het verhaal worden zo niet geanalyseerd, wat een mogelijke tekortkoming is van deze studie. De beoordelaars werd gevraagd om het fragment te beluisteren en vervolgens een van onderstaande uitspraken te selecteren:

(1) Deze spreker lijkt op basis van zijn taalgebruik afkomstig uit Vlaanderen en hanteert daarbij de Belgisch-Nederlandse standaardtaal;

(2) Deze spreker lijkt op basis van zijn taalgebruik afkomstig uit Vlaanderen en hanteert daarbij gemarkeerd dialect;

(3) Deze spreker lijkt op basis van zijn taalgebruik afkomstig uit Vlaanderen en hanteert daarbij tussentaal, een intermediair taalgebruik dat noch als Belgisch-Nederlandse standaardtaal noch als dialect kan ingedeeld worden;

(4) Deze spreker lijkt op basis van zijn taalgebruik niet uit Vlaanderen afkomstig

Wanneer beoordelaars label (2) kiezen, werd hen verder gevraagd om een keuze te maken tussen de vier Vlaamse dialectgebieden (ondersteund door een kaart van de dialectgebieden in Vlaanderen). Bij de keuze voor de vierde categorie werd de beoordelaar gevraagd zelf het accent of de variëteit uit het fragment nader te benoemen.

De eerste vraag die zich stelt bij de categorisering, is of en hoe vaak de beoordelaars hetzelfde label selecteren. Wanneer dat niet het geval is (bij 91 van de 260 personages), gaan we verder na hoe we de onenigheid tussen de beoordelaars kunnen duiden (zie Sectie 3.1 verderop). In het geval dat de beoordelaars wel hetzelfde label selecteren (bij de resterende 169 personages), gaan we uit van een 
duidelijk(er) herkenbare taalvariëteit. In deze meer gemarkeerde gevallen zijn we vervolgens geïnteresseerd in de sociale kenmerken van de personages, en in de vraag of bepaalde sociale kenmerken samenhangen met bepaalde variëteiten (zie Sectie 3.2 verderop). De precieze codering van de sociale kenmerken van de personages wordt in de volgende sectie besproken.

\subsection{Sociale kenmerken personages}

Deze studie hanteert een personagegebaseerde aanpak, die veronderstelt dat de talige (of ook stilistische) keuzes in fictie indices zijn van de persoonlijkheid van een personage: ze ondersteunen de karaktertekening (zie Bleichenbacher 2008: 30, Culpeper 2001) en krijgen sociale betekenis doordat ze worden toegeschreven aan specifieke personages en op die manier bepaalde heersende taalideologieën over taalvariatie in de film brengen (Androutsopoulos 2012a: 147). In films of andere visuele voorstellingen worden dergelijke talige keuzes ook verder ondersteund door meer materiële stilistische keuzes, zoals de kledij of de haartooi van het personage (Eckert 2008: 457). In de hoorspelen ontbreekt deze visuele input, waardoor de categorisering van de personages voornamelijk moet worden afgeleid uit de tekst, de verhaallijn, en in het bijzonder voor dit onderzoek, de taalkeuzes.

Voor dit onderzoek kijken we uitsluitend naar de gemarkeerde taalkeuzes, of naar wat Androutsopoulos stylizaton noemt: het proces waarbij taalvariëteiten en accenten op een saillante manier worden gebruikt in de hoorspelen, en op een gestereotypeerde of overdreven manier aan een personage worden gekoppeld, om het des te duidelijker te karakteriseren. Stylizing in deze betekenis duidt hier dus op een stereotype sociale betekenis - of in Silversteins (2003) termen indexicaliteit van de tweede orde - die zich al in de maatschappij bevindt en gebruikt wordt om een personage te kenmerken.

Binnen het indexicale veld (i.e. de waaier aan sociale betekenissen die een taalvorm, een gehele variëteit of een accent kan hebben, zie Eckert 2008: 464) duidt de indexicaliteit van de eerste orde (Silverstein 2003) op associaties tussen taalkundige kenmerken en groepen taalgebruikers (sociale categorieën zoals mannen, arbeidersklasse, oud). Voor dit onderzoek werken we met indexicaliteit van de tweede orde, wat associaties zijn tussen taalkundige kenmerken en sociale betekenissen die ideologisch verbonden zijn met een groep mensen (bv. stoer voor 'mannen'). Deze associaties ontstaan omdat mensen hun ideeën (sociale betekenis) over variëteiten/kenmerken gaan koppelen aan mensen die deze vormen gebruiken: wanneer bijvoorbeeld een linguïstische eigenschap vaak wordt gebruikt door hoogopgeleide jonge mannen, zal deze waarschijnlijk gekoppeld zijn aan kenmerken die (stereo)typisch geassocieerd zijn met deze jonge mannen, bijvoorbeeld 'jong', 'intelligent' of 'modern'. De studie van deze sociale betekenissen van de tweede orde legt met andere woorden ook de heersende ideologieën bloot over taalvariëteiten in een specifieke gemeenschap. Aangezien, zoals reeds aangegeven in sectie 1 , media een cruciale rol hebben in het voorleggen en verspreiden van bepaalde ideologische standpunten (Van Hoof 2013), gaan we ervan uit dat de betekenissen van de tweede orde in onze hoorspelen een reflectie zijn van ideologieën over taalvariatie in Vlaanderen.

Experimenteel attitudeonderzoek (het zogenaamde speaker evaluation-paradigma) onderzoekt al sinds jaren met succes de koppeling tussen taalvormen en deze indexicaliteit van de tweede orde (Ryan et al. 1988; Grondelaers et al. 2010). Om de sociale betekenis te achterhalen die gekoppeld wordt aan taalvariëteiten, gebruiken we drie indexicaliteitsdimensies van de tweede orde die door veelvuldig experimenteel onderzoek al zijn getest, namelijk de solidariteit tegenover de spreker, het prestige van de spreker en het dynamisme van de spreker. Deze dimensies kunnen worden beschouwd als verzamelnamen of labels voor dieperliggende evaluaties (of associaties) tegenover taalfenomenen of taalvariëteiten, waarbij zulke evaluaties gelden als sociale betekenissen van de tweede orde die aan taalfenomenen toegekend worden. 
De drie dimensies, die hieronder worden besproken, zijn geoperationaliseerd aan de hand van respectievelijk twee, vier en vier waarden (of in termen van attitudeonderzoek: verschillende schalen) waarvoor één beoordelaar de dataset gecodeerd heeft. Deze waarden zijn eveneens veel gebruikte attitudeschalen, maar werden aangepast aan de context van de luisterverhalen. Om de personages waarden toe te kennen op de variabelen baseren we ons op expliciete aanwijzingen in de verhaallijnen van de luisterverhalen, de beschrijvingen die andere personages of de verteller over hen geeft, de beschrijving van het personage in het begeleidend boek en reflecties over hun eigen persoonlijkheid. Een overzicht van deze variabelen en hun mogelijke waarden is te vinden in tabel 1 . Supplement $A$ bevat daarbij een codeboek met een overzicht en motivering van de codering van de sociale eigenschappen voor elk personage dat wordt besproken in Sectie 3, namelijk alle personages die het West-Vlaams en het Franse accent hanteren.

\begin{tabular}{|c|c|c|c|c|c|}
\hline \multirow{3}{*}{$\begin{array}{l}\text { Dimensie } \\
\text { Solidariteit }\end{array}$} & \multicolumn{5}{|l|}{ Variabelen } \\
\hline & \multicolumn{2}{|l|}{ Vriendelijk } & \multicolumn{2}{|l|}{ NA } & Onvriendelijk \\
\hline & Protagonist & Helper & \multicolumn{2}{|c|}{ Nevenpersonage } & Antagonist \\
\hline \multirow[t]{4}{*}{ Prestige } & \multicolumn{2}{|l|}{ Rijk } & \multicolumn{2}{|l|}{ NA } & Arm \\
\hline & \multicolumn{2}{|l|}{ Intelligent } & \multicolumn{2}{|l|}{ NA } & Dom \\
\hline & \multicolumn{2}{|l|}{ Beschaafd } & \multicolumn{2}{|l|}{ NA } & Onbeschaafd \\
\hline & \multicolumn{2}{|c|}{ Prestigieus beroep } & Neutraa & NA & Niet-prestigieus beroep \\
\hline \multirow[t]{4}{*}{ Dynamisme } & \multicolumn{2}{|l|}{ Enthousiast } & \multicolumn{2}{|l|}{ NA } & Ongemotiveerd \\
\hline & \multicolumn{2}{|l|}{ Stoer } & NA & & Laf \\
\hline & \multicolumn{2}{|l|}{ Cool } & \multicolumn{2}{|l|}{ NA } & Oubollig \\
\hline & \multicolumn{2}{|l|}{ Jong } & NA & & Oud \\
\hline
\end{tabular}

Tabel 1: Overzicht van de variabelen voor solidariteit, prestige en dynamisme met hun mogelijke waarden.

De solidariteit tegenover de personages is geoperationaliseerd aan de hand van de variabelen 'vriendelijkheid' en 'personagetype'. De variabele 'vriendelijkheid' is gebaseerd op de 'kindness'-schaal uit het matched guise-onderzoek van Lambert en collega's (1960; zie ook Grondelaers \& Speelman 2013). In onze codering zijn personages 'vriendelijk' wanneer ze zich ontfermen over of zich bekommeren om andere personages $(n=25)$, 'onvriendelijk' wanneer ze agressief zijn, gemeen zijn of een ander personage bewust tegenwerken ( $n=26)$, en ' $N A^{\prime}$ ' wanneer geen van beide van toepassing is ( $n=118) .{ }^{4}$ Zo krijgt bijvoorbeeld de Vos uit 'De Gouden Vogel' en 'Het Meisje met de Gouden Glimlach' de waarde 'vriendelijk' toegekend. Hij helpt immers niet alleen Tabil om de Gouden Vogel te vinden, maar hij heeft ook een spreekuur waarop hij verschillende dieren van het bos goede raad geeft zoals aan de koekoek om zijn ei in zijn eigen nest te leggen in plaats van in andere nesten.

Als tweede variabele geldt 'personagetype' als een indicatie voor de solidariteit tegenover de spreker, waarbij gebruik is gemaakt van Propps analyse van het toversprookje (Propp 1997). Hoewel Propp zeven soorten personages onderscheidt, blijken de held of (met een algemenere term, zie van Bork et al. 2012b) 'protagonist', de tegenstander of antagonist (van Bork et al. 2012a), en de helper het meest relevant te zijn voor de luisterverhalen. De resterende personages zijn aan een restcategorie toegevoegd. De protagonisten en helpers beschouwen we als personages met een hoge solidariteit, aangezien zij het meest positief in het verhaal aan bod komen. De antagonist heeft een lage solidariteit aangezien hij of zij de acties van de held steeds tegenwerkt. De resterende personages, of

\footnotetext{
${ }^{4}$ Het label 'NA' wordt ook gebruikt voor personages die doorheen het verhaal zowel de positieve als negatieve waarde van een schaal toegekend krijgen, waarbij het label dus eerder 'ongedefinieerd' betekent. Een voorbeeld hiervan is te vinden in voetnoot 8 , bij de bespreking van Wéralène uit 'De Vlo en De Professor'.
} 
nevenpersonages, worden gecodeerd als neutrale personages. De dataset bevat zo 13 protagonisten, 9 helpers, 10 antagonisten en 137 nevenpersonages.

Het prestige van de personages is geoperationaliseerd aan de hand van vier variabelen. Als eerste zijn de personages gecodeerd voor de 'rijkdom' van het personage, gebaseerd op de 'wealthy-poor'-schaal uit het onderzoek van Ryan en Carranza (1975; zie ook Grondelaers \& Speelman 2013). Personages worden gecodeerd als 'rijk' of 'arm' op basis van passages waarbij ze respectievelijk als rijk of arm beschreven worden door de verteller of andere personages, of wanneer blijkt dat ze veel of weinig geld of bezittingen hebben. Ze worden ingedeeld als 'NA' wanneer geen van beide van toepassing is. Als voorbeeld kan daarbij de Keizer uit 'De Nachtegaal' besproken worden, die we coderen als rijk aangezien de verteller hem introduceert als iemand die woont in een 'wondermooi paleis, met wel 150 slaapkamers, 57 badkamers en 28 toiletten'. In de dataset zijn er 9 rijke personages, 8 arme personages en 152 personages met de waarde 'NA' met betrekking tot de variabele 'rijkdom'.

Als tweede zijn de personages gecodeerd voor de variabele 'intelligentie' (cf. 'intelligence'-schalen in Lambert et al. 1960 en Ryan \& Carranza 1975; zie ook Grondelaers \& Van Hout 2010). Personages worden als 'intelligent' beschouwd wanneer de verteller of andere personages ze als slim beschrijven, wanneer ze intelligente dingen doen of zeggen (zoals een ander personage verbeteren of een moeilijke term uitleggen). Als daarentegen personages als dom beschreven worden, als ze domme dingen doen of zeggen (zoals het antwoord niet weten op een simpele vraag), of als ze verbeterd worden door een ander personage, worden ze gecodeerd als 'dom'. De overige personages hebben de waarde 'NA' voor intelligentie. Zo bestaat de dataset uit 16 intelligente personages, 17 domme personages en 136 personages met de waarde 'NA'.

De derde prestigevariabele gaat na of personages beschaafd zijn of niet, gebaseerd op de 'educateduneducated'-schaal uit het onderzoek van Ryan en Carranza (1975; zie ook Grondelaers \& Van Hout 2010). Daarbij krijgt een personage de codering 'beschaafd' toegekend wanneer hij of zij dure woorden gebruikt, manieren erg belangrijk vindt, of beschreven wordt als een beschaafd persoon $(n=21)$. Personages worden daarentegen als 'onbeschaafd' gecodeerd als ze zo beschreven worden, als ze platvloers taalgebruik hanteren of als ze onfatsoenlijke dingen doen zoals boeren of scheten laten $(n=22)$. De overige personages $(n=126)$ worden als 'NA' gecodeerd.

Als laatste geldt ook het beroep van de personages als indicatie voor het prestige van de personages. Als maatstaf voor het prestige van de beroepen hebben we de 'Standard International Occupational Prestige Scale' (SIOPS) genomen, die ontwikkeld is door Treiman (1977). Die schaal bestaat uit prestigescores van 509 beroepen, met een bereik van 92 punten, gaande van -2 tot 90 . Om die scores vervolgens te vereenvoudigen in ons codeerschema van 'prestigieus beroep', 'neutraal beroep' en 'niet-prestigieus beroep', hebben we de geattesteerde scores in drie groepen onderverdeeld. Zo komen we tot een prestigieuze groep met scores van 60 tot 90 , een neutrale groep met scores van 29 tot 59 en een niet-prestigieuze groep met scores van -2 tot 28 . Van de 169 personages die gecodeerd zijn voor de sociale betekenis, zijn er voor deze variabele 70 personages buiten beschouwing gelaten: 41 omdat ze geen beroep uitoefenen of hun job niet bekend is en 29 omdat er voor hun beroep geen equivalent te vinden was in SIOPS (zoals bij koning(inn)en, prins(ess)en, keizers, baronnen, ...). In totaal bevat de dataset 20 personages die een prestigieus beroep uitoefenen (bijvoorbeeld een dokter of politiecommissaris), 58 die een neutraal beroep uitoefenen (bijvoorbeeld een cipier of secretaris), en 21 die een niet-prestigieus beroep uitoefenen (zoals een ober in een café of een poetsvrouw). Hoewel de indeling van beroepen in SIOPS als grote voordeel heeft dat we zo de codering kunnen objectiveren, geldt deze indeling slechts als een benadering van prestige. Zo worden bijvoorbeeld boeren en boerinnen als neutrale beroepen gecodeerd in deze indeling, maar stereotypisch wordt het beroep boer als 'niet-prestigieus beroep' beschouwd omwille van de associatie met ruraliteit (zie sectie 3.2.2). 
Bovendien houdt die codering ook geen rekening met de verhaallijn, waardoor bijvoorbeeld dokters die als incapabel gekarakteriseerd worden, toch een hoog prestige toegekend krijgen op het vlak van hun beroep (zie sectie 3.2.2).

Net zoals de prestigedimensie operationaliseren we ook de dynamismedimensie aan de hand van vier variabelen. De eerste dynamismevariabele is het enthousiasme van de personages (cf. 'enthousiastichesitant'-schaal uit Zahn \& Hopper 1985). Personages worden gecodeerd als 'enthousiast' wanneer ze glimlachen of luidop lachen of wanneer uit hun gedrag of woorden afgeleid kan worden dat ze blij zijn. Ze worden daarentegen gecodeerd als 'ongemotiveerd' wanneer ze niet gemotiveerd overkomen, zoals bijvoorbeeld door te zeuren of te klagen. De overige personages beschouwen we als 'NA'. In de dataset zijn er 35 enthousiaste personages, 8 ongemotiveerde personages en 126 personages met de waarde 'NA' met betrekking tot de variabele 'enthousiasme'.

Als tweede variabele voor dynamisme is voor elk personage bepaald of ze als stoer of laf gekarakteriseerd worden (cf. 'stoer-niet stoer'-schaal uit Grondelaers \& Van Gent 2019). Wanneer het personage niet bang is om te vechten of om enge dingen te doen, of als het personage beschreven wordt als stoer of dapper, beschouwen we het als een stoer personage. Als daarentegen het personage gekarakteriseerd wordt als een laf of angstig persoon coderen we het als een laf personage. Een voorbeeld daarbij zijn de twee politieagenten uit 'Het Meisje met de Gouden Glimlach', die 's nacht aan het patrouilleren zijn bij de renbaan Langevelde. Zij worden gecodeerd als laf omdat ze tijdens hun ronde een hele lijst opsommen van dingen waar ze bang van zijn, namelijk wanneer het donker is, water, spinnen, wanneer er iemand roept, tapdansende paarden en wanneer er iemand hard op een hoorn blaast. De overige personages krijgen de waarde 'NA' voor deze variabele. Zo zijn er 13 stoere personages, 4 laffe personages en 152 personages met de waarde 'NA'.

De derde dynamismevariabele gaat na of personages als cool of oubollig gekarakteriseerd kunnen worden (cf. 'cool-uncool' in Kristiansen 2009). Daarbij wordt een personage als 'cool' gecodeerd wanneer ze op de hoogte zijn van de trends of wanneer ze muzikanten zijn en als 'oubollig' wanneer ze de nadruk leggen op de 'goede oude tijd'. De overige personages coderen we als 'NA' met betrekking tot de variabele 'cool'. In de dataset zijn er 8 coole personages, 160 personages met de waarde 'NA' en is er 1 oubollig personage. Als laatste is de leeftijd van de personages bepaald (cf. 'young'-schaal in Maegaard 2005). Personages coderen we als 'jong' wanneer ze klinken als een kind of jongvolwassene (op basis van de eigenschappen van de stem, o.a. intonatie, timbre, toonhoogte, ...), of wanneer het personage in het verhaal beschreven wordt als jong $(n=32)$. Wanneer ze oud klinken of in het verhaal beschreven worden als oud, coderen we ze daarentegen als 'oud' ( $n=23)$. De overige personages coderen we als 'NA' op het vlak van leeftijd ( $n=114)$.

\section{Resultaten}

De resultaten van onze studie worden in twee stappen besproken. In sectie 3.1 bekijken we in eerste instantie het taalrepertoire in de 12 geselecteerde hoorspelen. Dat repertoire bestuderen we door enerzijds de gevallen te analyseren waar onenigheid bestaat in het oordeel van de beoordelaars, en anderzijds door in te zoomen op de relatieve aanwezigheid van de variëteiten en accenten waar de beoordelaars wel eenzelfde keuze maken. Deze gevallen met unanieme oordelen vormen het voorwerp van verdere analyse in sectie 3.2, waar we de focus verschuiven naar de sociale eigenschappen van de personages en zo in kaart brengen welke sociale betekenissen de duidelijk(er) herkenbare taalvariëteiten typisch indexeren in de hoorspelen. Daarbij kan in twee bewegingen worden gewerkt: van sociaal kenmerk naar variëteit, en van variëteit naar sociaal kenmerk. 


\subsection{Het taalrepertoire in Vlaamse hoorspelen: een diaglossisch continuüm?}

Zoals in Sectie 2.2 werd besproken, is er bij 91 van de 260 personages (35\%) geen overeenkomst in het oordeel van de beoordelaars over het taalgebruik van het personage. Tabel 2 bevat de combinaties van conflicterende labels in geval van onenigheid, die in drie groepen kunnen ingedeeld worden.

\begin{tabular}{|l|l|l|}
\hline Conflicterende labels & Aantal personages & Cumulatief percentage \\
\hline Belgisch-Nederlandse standaardtaal en tussentaal & 41 & $44,6 \%$ \\
\hline Brabants en tussentaal & 21 & $67,4 \%$ \\
\hline Limburgs en tussentaal & 2 & $69,6 \%$ \\
\hline Oost-Vlaams en tussentaal & 2 & $71,7 \%$ \\
\hline Brabants, West-Vlaams en tussentaal & 1 & $72,8 \%$ \\
\hline Oost-Vlaams en West-Vlaams & 7 & $80,4 \%$ \\
\hline Brabants en Oost-Vlaams & 1 & $81,5 \%$ \\
\hline Vreemde accenten $^{5}$ & 9 & $91,3 \%$ \\
\hline Restcategorie $^{6}$ & 8 & $100,0 \%$ \\
\hline
\end{tabular}

Tabel 2: Overzicht van de verdeling van de variëteiten en vreemde accenten wanneer er geen overeenkomst is tussen de beoordelaars.

De eerste en grootste groep betreft gevallen van onenigheid die gelinkt kunnen worden aan het diaglossische karakter van het Vlaamse taallandschap. Het merendeel van de conflictgevallen betreffen immers overgangszones in het Vlaamse variëteitencontinuüm. Bij 41 van die 91 personages (45\%) wordt zowel het standaardtaallabel als tussentaallabel geselecteerd. Deze personages bevinden zich in de overgangszone van Belgisch-Nederlandse standaardtaal en tussentaal. Nog eens 26 personages (29\%) bevinden zich aan de overgangszone van tussentaal naar dialect. Het merendeel van die 26 gevallen ( $n=21$ ) betreft conflicten tussen het label 'tussentaal' en het label 'Brabants', wat het idee van Brabant als centrum voor de verspreiding van tussentaal onderschrijft (Plevoets 2009). Verder betreffen 8 gevallen van onenigheid (9\%) conflict tussen aanpalende dialectgebieden (in 7 gevallen concurreren de labels West-Vlaams en Oost-Vlaams, in slechts 1 geval de labels Oost-Vlaams en Brabants). De categorieën die aan de fluïde overgangen in het Vlaamse variëteitencontinuüm zijn verbonden maken samen zo 75 van de 91 gevallen (82\%) van onenigheid uit in de perceptie van geschoolde taalkundigen.

De tweede en kleinere groep bevat 9 gevallen van onenigheid over de lokalisering van een personage buiten Vlaanderen. Dat resultaat kan te wijten zijn aan het feit dat de stemacteurs er in de beperkte tijd niet in slagen om de afkomst van het personage voldoende scherp neer te zetten of in het gebrek aan blootstelling van de taalkundige raters met bepaalde vreemde accenten van het Nederlands. De laatste groep bevat 8 gevallen van onenigheid die niet in bovenstaande categorieën onderverdeeld kunnen worden.

Tabel 3 bevat de verdeling over de labels voor de 169 personages waarbij er wel overeenkomst is tussen de beoordelaars (65 procent van het totaal van 260 personages). De tabel toont dat tussentaal en in mindere mate ook de Belgisch-Nederlandse standaardtaal de referentievariëteiten zijn in de

\footnotetext{
${ }^{5}$ Daarbij is er onduidelijkheid tussen: Engels- Belgisch-Nederlandse standaardtaal (1 personage); NederlandsNederlands- Belgisch-Nederlandse standaardtaal (2); Surinaams-Nederlands - Nederlands-Nederlands (1); Surinaams-Nederlands -etnolect (1); Frans-Duits (1); Indiaas-Oosters-Russisch-Zuiders (1); Indiaas-Arabisch (1); Grieks-niet nader bepaald vreemd accent (1).

${ }^{6}$ Daarbij is er onduidelijkheid tussen: Brabants-West-Vlaams (1 personage); Limburgs-Oost-Vlaams (1); FransOost-Vlaams (1); Frans-Brabants-Oost-Vlaams (3); Frans-Brabants (1); Frans- Belgisch-Nederlandse standaardtaal-Oost-Vlaams (1).
} 
luisterverhalen: ze worden gehanteerd door respectievelijk 36,7\% en $29,6 \%$ van de 169 personages. Bovendien blijkt uit figuur 1 dat de protagonisten enkel tussentaal en Belgisch-Nederlandse standaardtaal spreken, wat ook in de richting wijst dat die variëteiten als referentievariëteiten gelden, aangezien die personages het meeste aan het woord zijn. Het feit dat de Belgisch-Nederlandse standaardtaal een van de referentievariëteiten is, kan enerzijds toegeschreven worden aan het feit dat die variëteit kan optreden als mediataal in hedendaagse fictie (Van Hoof 2015), maar ook aan het feit dat protagonisten typisch de 'mainstream legitimate language' hanteren (Androutsopoulos 2012a). De meer prominente rol van tussentaal in de luisterverhalen weerspiegelt dan weer haar sterke positie in de gesproken taal van de Vlamingen (De Caluwe 2004, Delarue 2014), en bevestigt de sterke aanwezigheid van tussentaal in hedendaagse Vlaamse fictie (van Hoof 2015).

\begin{tabular}{|l|l|l|}
\hline Label & $\begin{array}{l}\text { Aantal personages } \\
\text { (absoluut) }\end{array}$ & $\begin{array}{l}\text { Aantal personages } \\
\text { (relatief) }\end{array}$ \\
\hline Tussentaal & 62 & $36,7 \%$ \\
\hline $\begin{array}{l}\text { Belgisch-Nederlandse } \\
\text { standaardtaal }\end{array}$ & 50 & $29,6 \%$ \\
\hline Brabants & 17 & $10,1 \%$ \\
\hline West-Vlaams & 13 & $7,7 \%$ \\
\hline $\begin{array}{l}\text { niet uit Vlaanderen } \\
-- \text { Frans accent }\end{array}$ & 6 & $3,6 \%$ \\
\hline $\begin{array}{l}\text { niet uit Vlaanderen } \\
-- \text { Nederlands-Nederlands accent }\end{array}$ & 5 & $3,0 \%$ \\
\hline $\begin{array}{l}\text { niet uit Vlaanderen } \\
-- \text { Duits accent }\end{array}$ & 4 & $2,4 \%$ \\
\hline $\begin{array}{l}\text { niet uit Vlaanderen } \\
-- \text { Engels accent }\end{array}$ & 4 & $2,4 \%$ \\
\hline $\begin{array}{l}\text { niet uit Vlaanderen } \\
-- \text { Indiaas accent }\end{array}$ & 2 & $1,2 \%$ \\
\hline Oost-Vlaams & 2 & $1,2 \%$ \\
\hline $\begin{array}{l}\text { niet uit Vlaanderen } \\
-- \text { Spaans accent }\end{array}$ & 2 & $1,2 \%$ \\
\hline $\begin{array}{l}\text { niet uit Vlaanderen } \\
-- \text { Surinaams-Nederlands }\end{array}$ & 1 & $0,6 \%$ \\
\hline $\begin{array}{l}\text { niet uit Vlaanderen } \\
-- \text { Oost-Europees accent }\end{array}$ & 1 & $0,6 \%$ \\
\hline Totaal & 169 & $100 \%$ \\
\hline
\end{tabular}

Tabel 3: Overzicht van de verdeling van de personages wanneer er overeenkomst is tussen de beoordelaars. 


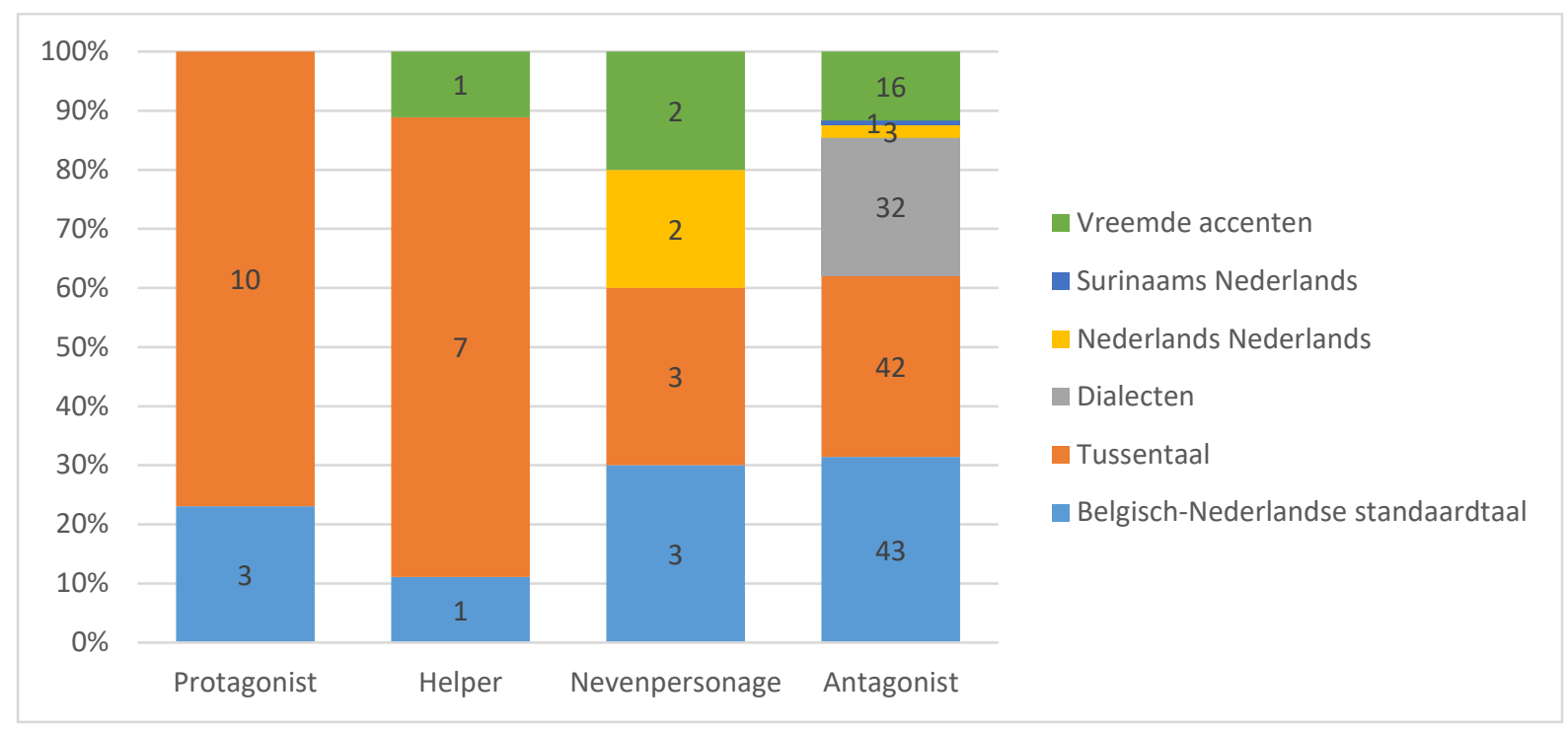

Figuur 1: Overzicht van de verdeling van de personages bij het personagetype over de verschillende variëteiten en accenten heen.

Wat daarnaast uit deze tabel naar voren komt, is dat er een breed aanbod aan variëteiten en accenten aanwezig is in de luisterverhalen. Zo zijn er naast de Belgisch-Nederlandse standaardtaal en tussentaal immers drie regionale variëteiten die gehanteerd worden, namelijk Brabants, West-Vlaams en OostVlaams, zes vreemde accenten, namelijk Frans, Duits, Engels, Spaans, Indiaas en Oost-Europees, alsook het Nederlands-Nederlands en Surinaams-Nederlands. Hoewel er een breed aanbod is, komen veel van die variëteiten en accenten slechts weinig voor. Drie op vier personages hanteert immers BelgischNederlandse standaardtaal, tussentaal of Brabants. Die beperkte rol van de Vlaamse dialecten zou een weerspiegeling kunnen zijn van het algemene patroon in Vlaanderen van dialectverlies (zie bijvoorbeeld Vandekerckhove 2009). Wanneer die regionale variëteiten en vreemde accenten echter wel aanwezig zijn in de luisterverhalen, drukken ze vaak een bepaalde indexicale waarde uit. Die sociale betekenis van de variëteiten en accenten vormt de focus van de volgende sectie.

\subsection{De indexicale waarde van duidelijk(er) herkenbare variëteiten}

De indexicale waarde van de duidelijk(er) herkenbare variëteiten in het taalrepertoire van de Vlaamse hoorspelen kan op twee manieren in kaart gebracht worden. Enerzijds kunnen we vertrekken vanuit de 10 sociale kenmerken die in Sectie 2.3 werden besproken, en kunnen we nagaan welke variëteiten en accenten aan elk van die kenmerken wordt gekoppeld (Appendix A). Andersom kunnen we vertrekken vanuit de variëteiten en accenten zelf en hun 'indexicale veld' in de hoorspelen in kaart brengen (Eckert 2008). Door na te gaan welke sociale kenmerken de personages die een bepaalde variëteit hanteren, bezitten, kunnen we het socialebetekenispotentieel van de variëteiten identificeren: 'Variables have indexical fields rather than fixed meanings because speakers use variables not simply to reflect or reassert their particular pre-ordained place on the social map but to make ideological moves' (Eckert 2008: 464). Beide perspectieven worden hieronder om beurt ingenomen, waarbij de meest opvallende patronen uit de dataset worden besproken. We richten ons hierbij enkel op de 169 personages waarbij de beoordelaars overeenstemden in keuze van taallabel. We gaan er namelijk van uit dat er bij deze personages een veel duidelijkere en gemarkeerde variëteit te horen is en dat die variëteit wellicht ook wordt gepercipieerd door het jonge doelpubliek. ${ }^{7}$

\footnotetext{
${ }^{7}$ Onenigheid tussen de beoordelaars over het accent of de variëteit impliceert echter niet dat de variëteit in kwestie geen karaktertekening onderstreept. Het lage agreement gehalte bij sommige variëteiten of accenten
} 


\subsubsection{Sociale kenmerken uitgelicht}

Appendix A bevat een tabel voor elk van de 10 sociale kenmerken die we in Sectie 2.3 identificeerden, waarin een overzicht wordt geboden van de variëteiten die personages met het betreffende kenmerk hanteren. Daarbij zien we typisch de verdeling uit tabel 3 weerspiegeld: proportioneel spreken de meeste personages tussentaal, gevolgd door personages die de Belgisch-Nederlandse standaardtaal hanteren. Er zijn echter twee interessante afwijkingen op dat algemene patroon.

Ten eerste valt op dat de onderlinge verhouding tussen tussentaal en Belgisch-Nederlandse standaardtaal verschuift bij enkele sociale kenmerken gekoppeld aan prestige, waarbij de standaardtaal proportioneel de meest gehanteerde variëteit wordt. Dit patroon is op te merken voor de waarden 'beschaafd', 'rijk' en 'intelligent', waarvoor de verdeling van de personages over de verschillende variëteiten en accenten heen te vinden is in tabel 4 . Uit die tabel blijkt dat van de 21 personages die de waarde 'beschaafd' toegekend krijgen er 12 Belgisch-Nederlandse standaardtaal spreken, wat neerkomt op 57 procent, in tegenstelling tot slechts 2 personages die tussentaal spreken (met daarnaast ook 2 personages met een Frans en Engels accent, en 1 personage dat het WestVlaams, het Brabants of het Duits accent hanteert). Gelijkaardige resultaten zien we ook bij de waarde 'rijk' terugkomen. Daarbij spreken immers 4 van de 9 personages die gecodeerd zijn met de waarde 'rijk' Belgisch-Nederlandse standaardtaal. Slechts 1 personage spreekt echter tussentaal. Als laatste kunnen we opmerken dat dat patroon, weliswaar in mindere mate, ook aanwezig is bij de waarde 'intelligent'. Daarbij spreken er immers 6 van de 16 personages met die waarde Belgisch-Nederlandse standaardtaal, wat goed is voor 38 procent, tegenover 4 personages tussentaal, wat goed is voor 25 procent.

\begin{tabular}{|l|l|l|l|l|l|l|}
\hline \multirow{2}{*}{ Variëteiten/accenten } & \multicolumn{4}{|l|}{ Aantal personages voor enkele waarden die prestige meten } \\
\cline { 2 - 8 } & Beschaafd & \multicolumn{2}{l|}{ Rijk } & \multicolumn{2}{l|}{ Intelligent } \\
\hline Tussentaal & 2 & $9,5 \%$ & 1 & $11,1 \%$ & 4 & $25,0 \%$ \\
\hline $\begin{array}{l}\text { Belgisch-Nederlandse } \\
\text { standaardtaal }\end{array}$ & 12 & $57,1 \%$ & 4 & $44,4 \%$ & 6 & $37,5 \%$ \\
\hline Brabants & & & & & & \\
\hline West-Vlaams & 1 & $4,8 \%$ & 1 & $11,1 \%$ & 0 & $0,0 \%$ \\
\hline Nederlands-Nederlands & 1 & $4,8 \%$ & 0 & $0,0 \%$ & 0 & $0,0 \%$ \\
\hline Duits & 0 & $0,0 \%$ & 1 & $11,1 \%$ & 2 & $12,5 \%$ \\
\hline Engels & 1 & $4,8 \%$ & 0 & $0,0 \%$ & 1 & $6,3 \%$ \\
\hline Frans & 2 & $9,5 \%$ & 1 & $11,1 \%$ & 2 & $12,5 \%$ \\
\hline Spaans & 2 & $9,5 \%$ & 0 & $0,0 \%$ & 1 & $6,3 \%$ \\
\hline
\end{tabular}

Tabel 4: Eerste afwijking op het algemene patroon: overzicht van het aantal personages bij de waarden 'beschaafd', 'rijk' en 'intelligent' voor de verschillende variëteiten/accenten.

Uit die resultaten komt dus naar voren dat de Belgisch-Nederlandse standaardtaal in de luisterverhalen typisch gebruikt wordt om de waarden 'rijk', 'intelligent' en 'beschaafd' te indexeren, wat ook verder ondersteund wordt wanneer we kijken naar de verdeling van de personages bij de negatieve tegenhangers van die waarden. In tabel 5 zien we immers dat bij de waarden 'onbeschaafd', 'arm' en 'dom' het algemene patroon in de andere richting verstoord wordt. Normaal gezien volgt op tussentaal

kan namelijk te wijten zijn aan het feit dat de beoordelaars niet allemaal hetzelfde gewicht hebben gegeven aan alle niveaus van variatie: sommigen geven wellicht een ander gewicht aan grammaticale en lexicale variatie, dan aan fonetische variatie. Een grammaticale standaardtaal met een licht regionale tongval (bijvoorbeeld Brabants) kan bijvoorbeeld door sommigen als tussentaal worden bestempeld, en door anderen toch Brabants. 
de Belgisch-Nederlandse standaardtaal als meest gehanteerde variëteit maar hier zien we dat het een regionale variëteit is die tussentaal opvolgt in plaats van Belgisch-Nederlandse standaardtaal waardoor de standaardtaal dan ook weinig aan bod komt. Zo zien we dat slechts 3 van de 22 personages die de waarde 'onbeschaafd' toegekend krijgen Belgisch-Nederlands spreken, wat goed is voor 14 procent. Bij de waarde 'arm' zien we een nog groter verschil aangezien er zelfs geen personages zijn die de Belgisch-Nederlandse standaardtaal spreken en die de waarde 'arm' toegekend krijgen, en ook bij de intelligentie van de personages treedt er een gelijkaardig patroon op. Zo spreken slechts 2 van 17 personages die als 'dom' gekarakteriseerd zijn de Belgisch-Nederlandse standaardtaal.

\begin{tabular}{|l|l|l|l|l|l|l|l|l|}
\hline \multirow{2}{*}{ Variëteiten/accenten } & \multicolumn{9}{|l|}{ Aantal personages } \\
\cline { 2 - 10 } & Onbeschaafd & \multicolumn{2}{l|}{ Arm } & \multicolumn{2}{l|}{ Dom } & \multicolumn{2}{l|}{ Onvriendelijk } \\
\hline Tussentaal & 8 & $36,4 \%$ & 7 & $87,5 \%$ & 5 & $29,4 \%$ & 11 & $42,3 \%$ \\
\hline Belgisch-Nederlandse standaardtaal & 3 & $13,6 \%$ & 0 & $0,0 \%$ & 2 & $11,8 \%$ & 4 & $15,4 \%$ \\
\hline Brabants & 4 & $18,2 \%$ & 0 & $0,0 \%$ & 3 & $17,6 \%$ & 6 & $23,1 \%$ \\
\hline West-Vlaams & 3 & $13,6 \%$ & 1 & $12,5 \%$ & 4 & $23,5 \%$ & 0 & $0,0 \%$ \\
\hline Oost-Vlaams & 2 & $9,1 \%$ & 0 & $0,0 \%$ & 1 & $5,9 \%$ & 0 & $0,0 \%$ \\
\hline Nederlands-Nederlands & 1 & $4,5 \%$ & 0 & $0,0 \%$ & 0 & $0,0 \%$ & 1 & $3,8 \%$ \\
\hline Duits & 0 & $0,0 \%$ & 0 & $0,0 \%$ & 1 & $5,9 \%$ & 0 & $0,0 \%$ \\
\hline Frans & 0 & $0,0 \%$ & 0 & $0,0 \%$ & 1 & $5,9 \%$ & 0 & $0,0 \%$ \\
\hline Engels & 0 & $0,0 \%$ & 0 & $0,0 \%$ & 0 & $0,0 \%$ & 1 & $3,8 \%$ \\
\hline Spaans & 0 & $0,0 \%$ & 0 & $0,0 \%$ & 0 & $0,0 \%$ & 2 & $7,7 \%$ \\
\hline Oost-Europees & 1 & $4,5 \%$ & 0 & $0,0 \%$ & 0 & $0,0 \%$ & 1 & $3,8 \%$ \\
\hline
\end{tabular}

Tabel 5: Tweede afwijking op het algemene patroon: overzicht van het aantal personages bij de waarden onbeschaafd', 'arm', 'dom' en 'onvriendelijk' voor de verschillende variëteiten/accenten.

Bovendien toont deze tabel dat de regionale variëteiten die proportioneel meer gehanteerd worden dan de Belgisch-Nederlandse standaardtaal het West-Vlaams en het Brabants zijn voor de prestigewaarden 'onbeschaafd', 'arm' en 'dom'. Meer bepaald blijkt dat voor de waarde 'onbeschaafd' 4 van de 22 personages Brabants spreken in vergelijking met 3 personages de Belgisch-Nederlandse standaardtaal. Ook bij de waarde 'arm' komt dit naar voren, maar dan voor het West-Vlaams: 1 personage met die waarde spreekt immers West-Vlaams tegenover 0 personages de BelgischNederlandse standaardtaal. Als laatste is dit ook het geval bij de waarde 'dom', voor zowel het Brabants als het West-Vlaams. Zo spreken er immers 3 van de 17 personages die gekarakteriseerd worden als 'dom' Brabants, en 4 personages West-Vlaams, tegenover 2 personages de BelgischNederlandse standaardtaal.

Als laatste kan ook de waarde 'onvriendelijk', die solidariteit meet, besproken worden als een afwijking op het algemene patroon. Daar zien we immers dat er meer personages zijn die Brabants spreken dan Belgisch-Nederlandse standaardtaal. Zo zijn er 6 personages die Brabants spreken, of 23 percent van alle personages die de waarde 'onvriendelijk' toegekend krijgen, tegenover 4 personages (of 15 procent van alle personages) die de Belgisch-Nederlandse standaardtaal spreken.

Op basis van deze bespreking kunnen we, met enige voorzichtigheid omwille van de beperkte grootte van de dataset, drie interim conclusies trekken. Als eerste tonen deze resultaten dat er niet alleen een sterke relatieve aanwezigheid van de Belgisch-Nederlandse standaardtaal is bij de positieve prestigekenmerken in vergelijking met tussentaal, maar ook dat de Belgisch-Nederlandse standaardtaal bij de negatieve prestigekenmerken weinig gebruikt wordt, of zelfs afwezig is. Daaruit kunnen we afleiden dat de Belgisch-Nederlandse standaardtaal niet alleen als referentievariëteit 
gebruikt wordt in de luisterverhalen, maar dat ze ook gebruikt wordt om prestige te indexeren. Die sociale betekenis van de Belgisch-Nederlandse standaardtaal in de hoorspelen wordt weerspiegeld in het Vlaams attitudeonderzoek, wat bijvoorbeeld blijkt uit de studies van Vandekerckhove en Cuvelier (2007), en Impe en Speelman (2008). Bovendien toont dit resultaat ook dat hoewel standaardtaal voornamelijk geassocieerd wordt met positief prestige, dat dit niet uitsluitend het geval is. Dat geeft aan dat ook die variëteit een indexicaal veld heeft, waarmee verschillende sociale betekenissen geassocieerd zijn. Als tweede komt naar voren dat er voor de waarde 'onvriendelijk' meer personages zijn die Brabants spreken dan de Belgisch-Nederlandse standaardtaal. Dat resultaat lijkt dus erop te wijzen dat het Brabants in de luisterverhalen niet alleen geassocieerd wordt met een laag prestige maar ook met een lage solidariteit. Dat is echter opmerkelijk aangezien uit vorig attitudeonderzoek gebleken is dat die variëteit typisch een hoge solidariteit toegekend wordt (Impe \& Speelman 2008, Vandekerckhove \& Cuvelier 2007). Als derde toont de tweede afwijking op het algemene patroon dat zowel de West-Vlaamse als de Brabantse variëteit gebruikt worden om een laag prestige te indexeren in de luisterverhalen, wat ook aansluit bij resultaten uit voorgaand attitudeonderzoek (zie bijvoorbeeld Lybaert 2017: 98). In wat volgt, zoomen we in op een van die twee variëteiten, waarbij we meer bepaald de sociale betekenis van het West-Vlaams in de luisterverhalen in detail bekijken. Zo kunnen we immers aantonen dat hoewel deze resultaten aangeven dat het West-Vlaams negatief prestige indexeert, het indexicale veld van die variëteit toch breder is dan enkel dat.

\subsubsection{Het indexicale veld van variëteiten en accenten in de hoorspelen: het West-Vlaams}

Om de sociale betekenis van het West-Vlaams in de luisterverhalen in kaart te brengen, lichten we vijf van de dertien personages uit die samen de breedheid van het indexicale veld illustreren. Bij elk personage geven we een overzicht van de sociale kenmerken van het personage alsook een motivering van de codering. Op het einde van deze sectie formuleren we een conclusie waarin we over de besproken personages heen een algemeen beeld van het indexicale veld van het West-Vlaams schetsen. We starten met een bespreking van Wéralène uit het hoorspel 'De Vlo en de Professor'. In tabel 6 is het coderingsprofiel te vinden van dat personage, waarbij de toegekende waarden grijs gekleurd zijn. ${ }^{8}$

\begin{tabular}{|c|c|c|c|c|c|}
\hline \multirow{3}{*}{$\begin{array}{l}\text { Dimensie } \\
\text { Solidariteit }\end{array}$} & \multicolumn{5}{|l|}{ Variabele } \\
\hline & \multicolumn{2}{|l|}{ Vriendelijk } & \multicolumn{2}{|l|}{ NA } & Onvriendelijk \\
\hline & Protagonist & Helper & \multicolumn{2}{|c|}{ Nevenpersonage } & Antagonist \\
\hline \multirow[t]{4}{*}{ Prestige } & \multicolumn{2}{|l|}{ Rijk } & \multicolumn{2}{|l|}{ NA } & Arm \\
\hline & \multicolumn{2}{|l|}{ Intelligent } & \multicolumn{2}{|l|}{ NA } & Dom \\
\hline & \multicolumn{2}{|l|}{ Beschaafd } & \multicolumn{2}{|l|}{ NA } & Onbeschaafd \\
\hline & \multicolumn{2}{|c|}{ Prestigieus beroep } & Neutraal & NA & Niet-prestigieus beroep \\
\hline \multirow[t]{4}{*}{ Dynamisme } & \multicolumn{2}{|l|}{ Enthousiast } & \multicolumn{2}{|l|}{ NA } & Ongemotiveerd \\
\hline & \multicolumn{2}{|l|}{ Stoer } & \multicolumn{2}{|l|}{ NA } & Laf \\
\hline & \multicolumn{2}{|l|}{ Cool } & \multicolumn{2}{|l|}{ NA } & Oubollig \\
\hline & \multicolumn{2}{|l|}{ Jong } & \multicolumn{2}{|l|}{ NA } & Oud \\
\hline
\end{tabular}

Tabel 6: Coderingsprofiel van Wéralène uit 'De Vlo en De Professor'.

\footnotetext{
${ }^{8}$ Bij dit personage houdt het label 'NA' op het vlak van 'vriendelijkheid' eerder 'ongedefinieerd' in, aangezien het personage zowel als 'vriendelijk' als 'onvriendelijk' gekarakteriseerd kan worden. Zo krijgt ze op basis van voorbeeld (1) het label 'vriendelijk' aangezien ze zich bekommert om de professor door hem een stukje zeep te geven, zonder dat hij daarvoor moet betalen, maar in andere delen blijkt dan weer dat ze ook als 'onvriendelijk' gekarakteriseerd kan worden. Zo verlaat ze de professor voor Fritz Ritz, waarbij ze al het geld meeneemt dat ze samen verdiend hebben.
} 
Wéralène is een van de personages waarbij het West-Vlaams wel degelijk negatief prestige indexeert. Zo wordt ze gekarakteriseerd in het verhaal als een arm personage, wat goed blijkt uit onderstaande passages:

(1) Passage uit 'De Vlo en De Professor', hoofdstuk 'Very Big Succes, Maar Not Voor Long', 01:05 $-01: 20^{9}$

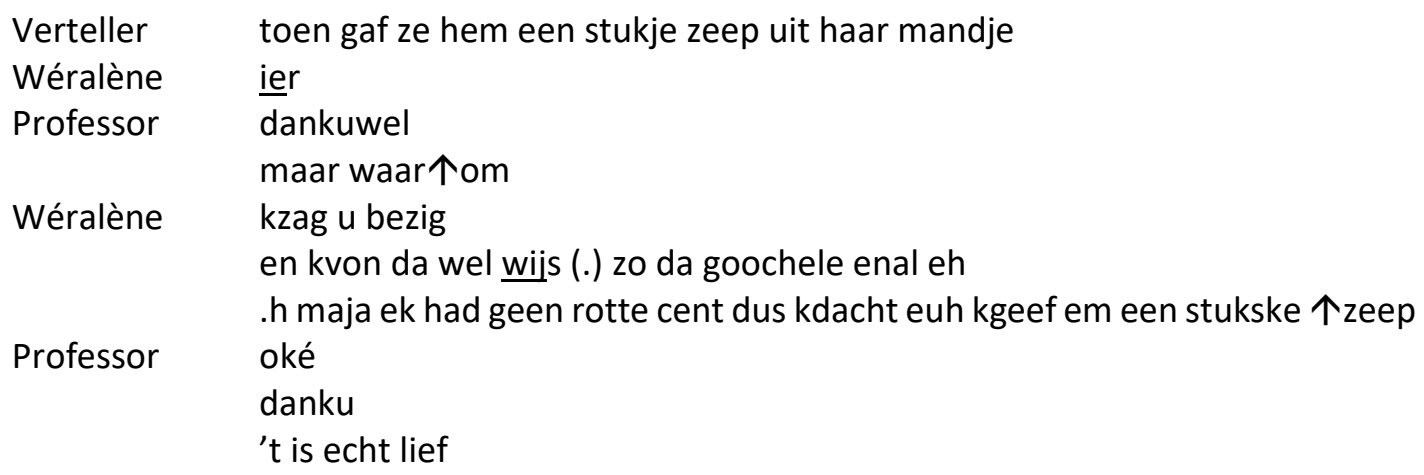

(2) Passage uit 'De Vlo en De Professor', hoofdstuk 'Very Big Succes, Maar Not Voor Long', 01:51 $-01: 57$
Professor waar woon $\uparrow \mathrm{jij}$
Wéralène on de bruhhe
Professor da meen je $\uparrow$ nie
zo'n mooi $\uparrow$ meisje
onder zo'n lelijke $\uparrow$ brugge

Wanneer de professor Wéralène dus leert kennen, is Wéralène iemand die zeepjes verkoopt op straat, die 'geen rotte cent' heeft en onder een brug woont. Hoewel Wéralène even later in het verhaal samen met de professor een goochelduo start waarbij ze volle zalen uitverkopen, blijken ze daar toch niet rijk van te worden. Frits Ritz, hun manager, houdt immers een groot deel van hun winst voor zich. Zo krijgen ze van al het geld dat ze verdienen met die optredens slechts 1 procent als loon, de overige 99 procent gaat naar hun manager. Bovendien wordt Wéralène, naast de codering als 'arm', ook gekarakteriseerd als een onbeschaafd personage. Ze wordt immers beschreven in het begeleidende boek als iemand die kan vloeken en ver kan spuwen: 'Op haar twaalfde begon ze te werken in de smidse. Ze leerde er vloeken, ver spuwen en vals spelen met de kaarten.'. Naast die twee negatieve labels op het vlak van prestige zien we dat Wéralène als zeepverkoopster en als goochelartieste in de neutrale categorie valt op vlak van het prestige van haar beroep. Als zeepverkoopster wordt ze immers onderverdeeld bij de groep '04521 Street Vendor, Peddler' wat geassocieerd wordt met een SIOPSscore van 33, en als goochelartieste hoort ze bij de groep '0179 Performing Artists', wat gelijkgesteld wordt met een score van 42 . Wanneer we dan de waarden voor de dynamismedimensie in wat meer detail bekijken, zien we dat Wéralène geassocieerd wordt met enkel positieve labels. Zo wordt ze gekarakteriseerd als jong omdat ze klinkt als een jongvolwassene. Bovendien krijgt ze ook de waarde 'enthousiast' toegekend. Zo toont onderstaande passage dat Wéralène als enige enthousiast reageert op de mislukte kaarttruc die de professor uitvoert op straat:

(3) Passage uit 'De Vlo en De Professor', hoofdstuk 'Very Big Succes, Maar Not Voor Long', 00:39 $-00: 58$

Verteller de volgende ochtend stond de professor op de hoek van een straat

\footnotetext{
${ }^{9}$ De fragmenten zijn getranscribeerd met behulp van vereenvoudigde conversatieanalytische richtlijnen (Jefferson, 2004).
} 


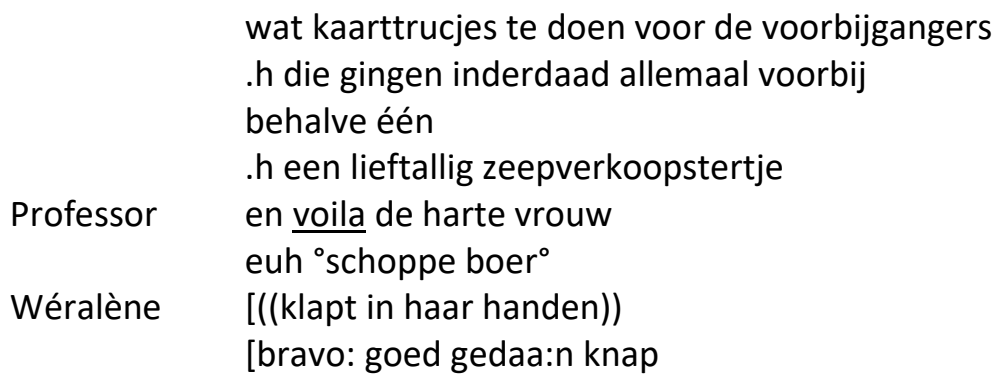

Een tweede personage dat besproken kan worden is de keukenmeid, die optreedt als interimsecretaris, uit 'De Gouden Vogel'. Een overzicht van de toegekende waarden is te vinden in tabel 7.

\begin{tabular}{|c|c|c|c|c|c|}
\hline \multirow{3}{*}{$\begin{array}{l}\text { Dimensie } \\
\text { Solidariteit }\end{array}$} & \multicolumn{5}{|l|}{ Variabele } \\
\hline & \multicolumn{2}{|l|}{ Vriendelijk } & \multicolumn{2}{|l|}{ NA } & Onvriendelijk \\
\hline & Protagonist & Helper & \multicolumn{2}{|c|}{ Nevenpersonage } & Antagonist \\
\hline \multirow[t]{4}{*}{ Prestige } & \multicolumn{2}{|l|}{ Rijk } & \multicolumn{2}{|l|}{ NA } & Arm \\
\hline & \multicolumn{2}{|l|}{ Intelligent } & \multicolumn{2}{|l|}{ NA } & Dom \\
\hline & \multicolumn{2}{|l|}{ Beschaafd } & \multicolumn{2}{|l|}{ NA } & Onbeschaafd \\
\hline & \multicolumn{2}{|c|}{ Prestigieus beroep } & Neutraal & NA & Niet-prestigieus beroep \\
\hline \multirow[t]{4}{*}{ Dynamisme } & \multicolumn{2}{|l|}{ Enthousiast } & \multicolumn{2}{|l|}{ NA } & Ongemotiveerd \\
\hline & \multicolumn{2}{|l|}{ Stoer } & \multicolumn{2}{|l|}{ NA } & Laf \\
\hline & \multicolumn{2}{|l|}{ Cool } & \multicolumn{2}{|l|}{ NA } & Oubollig \\
\hline & \multicolumn{2}{|l|}{ Jong } & \multicolumn{2}{|l|}{ NA } & Oud \\
\hline
\end{tabular}

Tabel 7: Coderingsprofiel van de keukenmeid/secretaris uit 'De Gouden Vogel'.

Uit het coderingsprofiel van de keukenmeid blijkt dat het West-Vlaams bij dit personages negatief prestige indexeert, aangezien ze zowel het label 'dom' als het label 'niet-prestigieus beroep' toegekend krijgt. Haar codering als dom heeft ze te danken aan onderstaande passage in het luisterverhaal waarin de koning aan haar vraagt hoeveel gouden appels hij nog heeft.

(4) Passage uit ‘De Gouden Vogel', hoofdstuk 'Eén Appel Armer', 00:52 - 01:04

\begin{tabular}{|c|c|}
\hline Koning & $\begin{array}{l}\text {.h bon } \\
\text { ((zucht)) }\end{array}$ \\
\hline & hoeveel appels heb ik $\uparrow$ nog \\
\hline Keukenmeid & $\begin{array}{l}\text { euh der ware der zeven der is der een weg dus da maakt } \\
\text { wacht oor } \\
{ }^{\circ} \text { zeven gepluimde kiekes in een pot doen } \\
\text { blijve der over zes }{ }^{\circ} \text { gepluimde kie- } \\
\text { appels, appels, zes appels }\end{array}$ \\
\hline
\end{tabular}

Om te kunnen antwoorden op die vraag moet ze een simpele rekensom maken, namelijk zeven min één, maar dat loopt niet van een leien dakje. Zo moet ze de getallen eerst vergelijken met kippen die ze in een kookpot steekt. Daarnaast heeft ze ook een niet-prestigieus beroep aangezien ze als keukenmeid slechts een SIOPS-score heeft van 22 (deel van de groep '05312 Cook's Helper'). Merk daarbij op dat we de codering baseren op haar beroep als keukenmeid en niet als secretaris, aangezien duidelijk wordt gemaakt in het verhaal dat deze taak slechts een voorlopige oplossing is nu er zoveel personeel van de koning vertrokken is.

Als derde personage bij het West-Vlaams bespreken we de Boerin uit 'De Wilde Zwanen', waarvan het coderingsprofiel te vinden is in tabel 8 . 


\begin{tabular}{|c|c|c|c|c|c|}
\hline \multirow{3}{*}{$\begin{array}{l}\text { Dimensie } \\
\text { Solidariteit }\end{array}$} & \multicolumn{5}{|l|}{ Variabele } \\
\hline & \multicolumn{2}{|l|}{ Vriendelijk } & \multicolumn{2}{|l|}{ NA } & Onvriendelijk \\
\hline & Protagonist & Helper & \multicolumn{2}{|c|}{ Nevenpersonage } & Antagonist \\
\hline \multirow[t]{4}{*}{ Prestige } & \multicolumn{2}{|l|}{ Rijk } & \multicolumn{2}{|l|}{$\overline{N A}$} & Arm \\
\hline & \multicolumn{2}{|l|}{ Intelligent } & \multicolumn{2}{|l|}{ NA } & Dom \\
\hline & \multicolumn{2}{|l|}{ Beschaafd } & \multicolumn{2}{|l|}{ NA } & Onbeschaafd \\
\hline & \multicolumn{2}{|c|}{ Prestigieus beroep } & Neutraal & NA & Niet-prestigieus beroep \\
\hline \multirow[t]{4}{*}{ Dynamisme } & \multicolumn{2}{|l|}{ Enthousiast } & \multicolumn{2}{|l|}{ NA } & Ongemotiveerd \\
\hline & \multicolumn{2}{|l|}{ Stoer } & \multicolumn{2}{|l|}{ NA } & Laf \\
\hline & \multicolumn{2}{|l|}{ Cool } & \multicolumn{2}{|l|}{ NA } & Oubollig \\
\hline & \multicolumn{2}{|l|}{ Jong } & \multicolumn{2}{|l|}{ NA } & Oud \\
\hline
\end{tabular}

Tabel 8: Coderingsprofiel van de Boerin uit 'De Wilde Zwanen'.

Wat betreft de prestigedimensie blijkt dat de boerin gecodeerd wordt als een onbeschaafd personage, wat afgeleid is uit een liedje dat ze zingt over haar leven als boerin. Dat liedje zit immers vol met referenties naar 'onfatsoenlijke' zaken zoals uitwerpselen en scheldwoorden, waar de verteller dan ook op reageert. Enkele voorbeelden daarvan zijn te vinden in onderstaande transcripties.

(5) Passage uit 'De Wilde Zwanen', hoofdstuk 'Hoe Elisa Bij De Boer In De Aap Gelogeerd Was', 02:49-3:00

Boerin elke ochtend bij tkrieken van den dag klimt de haan op een tak .h en kraait hij iedereen wakker de vuile zak

Verteller helaba

Boerin euh zak euh

zakdoeken moeten in de was

(6) Passage uit 'De Wilde Zwanen', hoofdstuk 'Hoe Elisa Bij De Boer In De Aap Gelogeerd Was', 03:02-03:09

Boerin een boer begint een dag met een stevige prot

Verteller eh

Boerin $\quad$-eïnerijke maaltijd

Verteller ah

(7) Passage uit 'De Wilde Zwanen', hoofdstuk 'Hoe Elisa Bij De Boer In De Aap Gelogeerd Was', 04:02-04:12

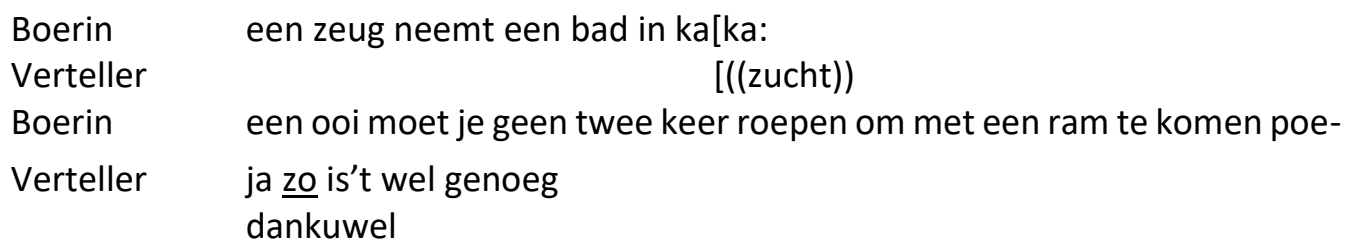

Daarnaast zien we dat ze als boer gecodeerd wordt als iemand met een neutraal beroep. Ze behoort immers tot de groep '0611 General Farmers', die een SIOPS-score van 40 toegekend krijgen. Die codering is echter problematisch aangezien we dat beroep intuïtief zouden associëren met een 'nietprestigieus beroep' (zie voor een verdere bespreking van de tekortkomingen van de beroepsschaal de besprekingen bij de overzichtstabellen voor het West-Vlaams en Frans accent). Wanneer we de 
solidariteit van het personage wat meer in detail bekijken, zien we dat het personage geportretteerd wordt als een vriendelijk personage. Op het punt in het verhaal waarin de boerin als personage optreedt, heeft de stiefmoeder van Elisa haar echtgenoot overtuigd om zijn dochter bijna tien jaar naar een boerengezin te sturen. Elisa komt dan ook terecht bij de boerin, waarbij de verteller in onderstaande passage er de nadruk oplegt dat ze goed voor Elisa gezorgd heeft, ondanks de weinige middelen die ze heeft.

(8) Passage uit 'De Wilde Zwanen', hoofdstuk 'Hoe Elisa Bij De Boer In De Aap Gelogeerd Was', 02:14-02:19

Verteller de boerin zorgde zo goed voor Elisa als ze kon maar het was fnatuurlijk geen paleisf

Als laatste zien we ook dat het personage bij de dynamismeschalen de waarde 'enthousiast' toegekend krijgt. Die codering is gebaseerd op het liedje dat ze vol overgave en enthousiasme zingt over haar leven als een boerin. Na het liedje dat vol onfatsoenlijke zaken zit, haalt ze ook lacherig aan dat de verteller niet veel gewoon is:

(9) Passage uit 'De Wilde Zwanen', hoofdstuk 'Hoe Elisa Bij De Boer In De Aap Gelogeerd Was', 04:12-04:20

Boerin $\quad € \uparrow o o h$ meneer de verteller is precies nie veel he $\uparrow w o o n$ eh van tstad 个zekerf

allez kom tis goe

vertelt mo voort

Als vierde personage bespreken we Dokter Fruit uit 'De Vlo en De Professor', waarvan het coderingsprofiel te vinden is in tabel 9.

\begin{tabular}{|c|c|c|c|c|c|}
\hline \multirow{3}{*}{$\begin{array}{l}\text { Dimensie } \\
\text { Solidariteit }\end{array}$} & \multicolumn{5}{|l|}{ Variabele } \\
\hline & \multicolumn{2}{|l|}{ Vriendelijk } & \multicolumn{2}{|l|}{ NA } & Onvriendelijk \\
\hline & Protagonist & Helper & \multicolumn{2}{|c|}{ Nevenpersonage } & Antagonist \\
\hline \multirow[t]{4}{*}{ Prestige } & \multicolumn{2}{|l|}{ Rijk } & \multicolumn{2}{|l|}{ NA } & Arm \\
\hline & \multicolumn{2}{|l|}{ Intelligent } & \multicolumn{2}{|l|}{ NA } & Dom \\
\hline & \multicolumn{2}{|l|}{ Beschaafd } & \multicolumn{2}{|l|}{ NA } & Onbeschaafd \\
\hline & \multicolumn{2}{|c|}{ Prestigieus beroep } & Neutraal & NA & Niet-prestigieus beroep \\
\hline \multirow[t]{4}{*}{ Dynamisme } & \multicolumn{2}{|l|}{ Enthousiast } & \multicolumn{2}{|l|}{ NA } & Ongemotiveerd \\
\hline & \multicolumn{2}{|l|}{ Stoer } & \multicolumn{2}{|l|}{ NA } & Laf \\
\hline & \multicolumn{2}{|l|}{ Cool } & \multicolumn{2}{|l|}{ NA } & Oubollig \\
\hline & \multicolumn{2}{|l|}{ Jong } & \multicolumn{2}{|l|}{ NA } & Oud \\
\hline
\end{tabular}

Tabel 9: Coderingsprofiel van Dokter Fruit uit 'De Vlo en De Professor'.

Qua prestige zien we dat het West-Vlaams van Dokter Fruit zowel negatief prestige als positief prestige indexeert, respectievelijk omwille van de toekenning van de labels 'dom' en 'prestigieus beroep'. Zijn karakterisering als dom heeft hij te danken aan het feit dat hij geportretteerd wordt als een incapabele dokter die zelf geen diagnose stelt, maar die enkel de verteller herhaalt:

(10) Passage uit 'De Vlo en De Professor', hoofdstuk 'Very Big Succes, Maar Not Voor Long', 00:13 $-00: 34$

Verteller dokter fruit .h volgens mij stevent de professor af op een depressie de arme man 


$\begin{array}{ll}\text { Dokter Fruit } & \begin{array}{l}\text { wat denkt u er } \uparrow \text { ja ehm } \\ \text { kijk eh nie waar } . \mathrm{h} \mathrm{hh} \\ \text { volgens mij ehm }\end{array} \\ \text { Verteller } & \begin{array}{l}\mathrm{mhm} \\ \text { Dokter Fruit }\end{array} \\ & \begin{array}{l}\text { hh stevent de professor hh af euh op een depressie eh } \\ \text { euh de arme man }\end{array}\end{array}$

Zijn ander kenmerk als een prestigieus beroep hebbend krijgt hij door zijn beroep als arts. Dat beroep krijgt immers een SIOPS-score van 78, aangezien het hoort onder de groep '0061 Medical Doctors'. Daarnaast wordt het personage ook gekarakteriseerd als oud aangezien hij een lage en hese stem heeft waarbij hij zuchtend lijkt te spreken door een slechte fysieke toestand.

Als laatste kunnen we de Dorpsman uit 'De Bremers Stadsmuzikanten' bespreken, waarvan het coderingsprofiel te vinden is in tabel 10.

\begin{tabular}{|c|c|c|c|c|c|}
\hline \multirow{3}{*}{$\frac{\text { Dimensie }}{\text { Solidariteit }}$} & \multicolumn{5}{|l|}{ Variabele } \\
\hline & \multicolumn{2}{|l|}{ Vriendelijk } & \multicolumn{2}{|l|}{$\overline{N A}$} & Onvriendelijk \\
\hline & Protagonist & Helper & \multicolumn{2}{|c|}{ Nevenpersonage } & Antagonist \\
\hline \multirow[t]{4}{*}{ Prestige } & \multicolumn{2}{|l|}{ Rijk } & \multicolumn{2}{|l|}{$\overline{N A}$} & Arm \\
\hline & \multicolumn{2}{|l|}{ Intelligent } & \multicolumn{2}{|l|}{ NA } & Dom \\
\hline & \multicolumn{2}{|l|}{ Beschaafd } & \multicolumn{2}{|l|}{ NA } & Onbeschaafd \\
\hline & \multicolumn{2}{|c|}{ Prestigieus beroep } & Neutraal & NA & Niet-prestigieus beroep \\
\hline \multirow[t]{4}{*}{ Dynamisme } & \multicolumn{2}{|l|}{ Enthousiast } & \multicolumn{2}{|l|}{ NA } & Ongemotiveerd \\
\hline & \multicolumn{2}{|l|}{ Stoer } & \multicolumn{2}{|l|}{ NA } & Laf \\
\hline & \multicolumn{2}{|l|}{ Cool } & \multicolumn{2}{|l|}{ NA } & Oubollig \\
\hline & \multicolumn{2}{|l|}{ Jong } & \multicolumn{2}{|l|}{ NA } & Oud \\
\hline
\end{tabular}

Tabel 10: Coderingsprofiel van de Dorpsman uit 'De Bremers Stadsmuzikanten'.

Het West-Vlaams van de dorpsman lijkt hier positief prestige te indexeren aangezien hij gekarakteriseerd wordt als een beschaafd personage in het luisterverhaal. Die codering is gebaseerd op een interactie tussen de dorpsman en de boer, hier toegevoegd bij (11), waarbij de boer meerdere keren vloekt waarop de dorpsman verontwaardigd reageert. Aangezien hij het onbeschaafd gedrag van de boer opmerkt en hem erop aanspreekt, coderen we hem dan ook als beschaafd.

(11) Passage uit 'De Bremers Stadsmuzikanten', hoofdstuk 'De Ezelin', 03:31 - 03:37

$\begin{array}{ll}\text { Boer } & \text { hadverde hadverde hadverde hadverde } \\ \text { Dorpsman } & \text { helaba (.) nie vloeken eh seh } \\ & \text { hod ziet } \mathrm{u}\end{array}$

\begin{tabular}{|l|l|l|l|}
\hline Dimensie & \multicolumn{2}{|l|}{ Variabele } & Onvriendelijk \\
\hline \multirow{3}{*}{ Solidariteit } & Vriendelijk $(n=1)$ & NA $(n=12)$ & Antagonist \\
\cline { 2 - 4 } & Protagonist $\quad$ Helper & $\begin{array}{l}\text { Nevenpersonage } \\
(n=13)\end{array}$ & Arm $(n=1)$ \\
\hline \multirow{3}{*}{ Prestige } & Rijk & NA $(n=12)$ & Dom $(n=4)$ \\
\cline { 2 - 4 } & Intelligent & NA $(n=9)$ & Onbeschaafd $(n=3)$ \\
\cline { 2 - 4 } & Beschaafd $(n=1)$ & NA $(n=9)$ & \\
\hline
\end{tabular}




\begin{tabular}{|l|l|l|l|l|}
\cline { 2 - 4 } & Prestigieus beroep $(n=2)$ & $\begin{array}{l}\text { Neutraal } \\
(n=5)\end{array}$ & NA $(n=5)$ & $\begin{array}{l}\text { Niet-prestigieus beroep } \\
(n=1)\end{array}$ \\
\hline \multirow{3}{*}{ Dynamisme } & Enthousiast $(n=3)$ & NA $(n=9)$ & Ongemotiveerd $(n=1)$ \\
\cline { 2 - 4 } & Stoer & NA $(n=13)$ & Laf \\
\cline { 2 - 4 } & Cool & NA $(n=13)$ & Oubollig \\
\cline { 2 - 4 } & Jong $(n=1)$ & NA $(n=11)$ & Oud $(n=1)$ \\
\hline
\end{tabular}

Tabel 11: Coderingsoverzicht voor het West-Vlaams.

Over het algemeen zien we in de overzichtstabel 11 dat de personages die West-Vlaams spreken vaak een waarde toegekend krijgen op de prestigeschalen en dan meer bepaald de negatieve labels zoals 'dom', 'arm' en 'onbeschaafd'. Het socialebetekenispotentieel van het West-Vlaams lijkt zich dus voornamelijk te situeren op het vlak van negatief prestige, wat een resultaat is wat ook in vorig attitudeonderzoek naar voren komt (zie bijvoorbeeld Impe \& Speelman 2008, Lybaert 2017, Vandekerckhove \& Cuvelier 2007). Dat neemt echter niet weg dat het socialebetekenispotentieel van de West-Vlaamse variëteit in de luisterverhalen breder is dan enkel die sociale betekenis. Zo zijn er immers ook West-Vlaamse personages die geassocieerd worden met een prestigieus beroep of beschaafdheid, wat de andere kant van de prestigeschaal aanwijst. Daarnaast is er ook een WestVlaams personage dat als vriendelijk gekarakteriseerd is, en zien we ook beide uitersten van de dynamismeschalen terugkomen aangezien er zowel voor de waarden 'oud' als 'jong' gecodeerd is, net als de waarden 'enthousiast' en 'ongemotiveerd'. Merk daarbij wel op dat de aanduiding van een prestigieus beroep niet zonder problemen is. Zoals al besproken in sectie 3.2, geldt de indeling van de beroepen slechts als een benadering van prestige. Dat wordt duidelijk wanneer we de Boerin uit 'De Wilde Zwanen' bespreken. Hoewel we haar immers een neutraal label toekennen voor haar beroep op basis van de SIOPS-indeling, wordt stereotypisch het beroep boer als 'niet-prestigieus beroep' beschouwd omwille van de associatie met ruraliteit. Daarnaast blijkt ook dat Dokter Fruit gekarakteriseerd wordt als iemand met een prestigieus beroep omwille van zijn job als arts. Uit de verhaallijn blijkt echter dat hij eerder als een incapabele arts gecodeerd moet worden aangezien hij enkel de verteller herhaalt en zelf geen diagnose stelt. De vraag rijst dan ook of die codering van 'prestigieus beroep' wel correct is voor Dokter Fruit. Wat bovendien ook blijkt uit de tabel is dat de personages die West-Vlaams spreken allemaal nevenpersonages zijn. Hoewel er dus wel wat personages zijn die een regionale variëteit hanteren die geassocieerd is met een sociale betekenis, is die rol toch niet weggelegd voor de hoofdpersonages. Dat onderschrijft dan ook onze conclusie dat standaardtaal en tussentaal de referentievariëteiten zijn. Al bij al kunnen we dus concluderen dat hoewel het indexicale veld van het West-Vlaams overwegend de nadruk legt op een laag prestige, het zich niet tot die sociale betekenis beperkt.

\subsubsection{Het indexicale veld van variëteiten en accenten in de hoorspelen: het Frans accent}

Naast het West-Vlaams zoomen we ook in op het indexicale veld van het Frans als casestudy. Omwille van de complexe geschiedenis van taalcontact met het Frans in Vlaanderen is het immers aannemelijk dat de personages die een Frans accent spreken een breedheid aan sociale betekenissen zullen vertonen. Er zijn in totaal zes personages die het Franse accent hanteren, waarvan we er in deze sectie drie zullen bespreken. Die personages zijn immers de enige personages waarbij er andere waarden dan neutrale of ' $N A^{\prime}$-waarden optreden bij de drie dimensies. Als eerste komen de Dokters uit 'De Nachtegaal' aan bod, waarvan het coderingsprofiel toegevoegd is in tabel $12 .{ }^{10}$

\footnotetext{
${ }^{10}$ De 'dokters' zijn als één personage beschouwd omdat de verschillende dokters moeilijk uit elkaar te houden waren: ze spreken immers allemaal met een Frans accent en hebben een gelijkaardige stem hebben, waardoor het niet duidelijk is hoeveel dokters er precies zijn en wie er net wat zegt.
} 


\begin{tabular}{|c|c|c|c|c|c|}
\hline \multirow{3}{*}{$\begin{array}{l}\text { Dimensie } \\
\text { Solidariteit }\end{array}$} & \multicolumn{5}{|l|}{ Variabele } \\
\hline & \multicolumn{2}{|l|}{ Vriendelijk } & \multicolumn{2}{|l|}{ NA } & Onvriendelijk \\
\hline & Protagonist & Helper & \multicolumn{2}{|c|}{ Nevenpersonage } & Antagonist \\
\hline \multirow[t]{4}{*}{ Prestige } & \multicolumn{2}{|l|}{ Rijk } & \multicolumn{2}{|l|}{$\overline{N A}$} & Arm \\
\hline & \multicolumn{2}{|l|}{ Intelligent } & \multicolumn{2}{|l|}{ NA } & Dom \\
\hline & \multicolumn{2}{|l|}{ Beschaafd } & \multicolumn{2}{|l|}{ NA } & Onbeschaafd \\
\hline & \multicolumn{2}{|c|}{ Prestigieus beroep } & Neutraal & NA & Niet-prestigieus beroep \\
\hline \multirow[t]{4}{*}{ Dynamisme } & \multicolumn{2}{|l|}{ Enthousiast } & \multicolumn{2}{|l|}{ NA } & Ongemotiveerd \\
\hline & \multicolumn{2}{|l|}{ Stoer } & \multicolumn{2}{|l|}{ NA } & Laf \\
\hline & \multicolumn{2}{|l|}{ Cool } & \multicolumn{2}{|l|}{ NA } & Oubollig \\
\hline & \multicolumn{2}{|l|}{ Jong } & \multicolumn{2}{|l|}{ NA } & Oud \\
\hline
\end{tabular}

Tabel 12: Coderingsprofiel van de Dokters uit 'De Nachtegaal'.

Qua prestige zien we dat het Frans van de dokters zowel negatief prestige als positief prestige indexeert, respectievelijk omwille van de toekenning van de labels 'dom' en 'prestigieus beroep'. Hun codering als dom is te wijten aan het feit dat ze geportretteerd worden als dokters die geen diagnose kunnen stellen en elkaar tegenspreken. Wanneer de keizer aangeeft dat hij niet meer in bad wilt, wat zijn favoriete bezigheid is, roept de hofmeester de hulp in van de dokters. In een poging om de oorzaak van zijn ziekte te bepalen, volgt onderstaande interactie:

(12) Passage uit 'De Nachtegaal', hoofdstuk 'De Keizer Wilt Niet Meer in Bad', 04:26 - 04:46

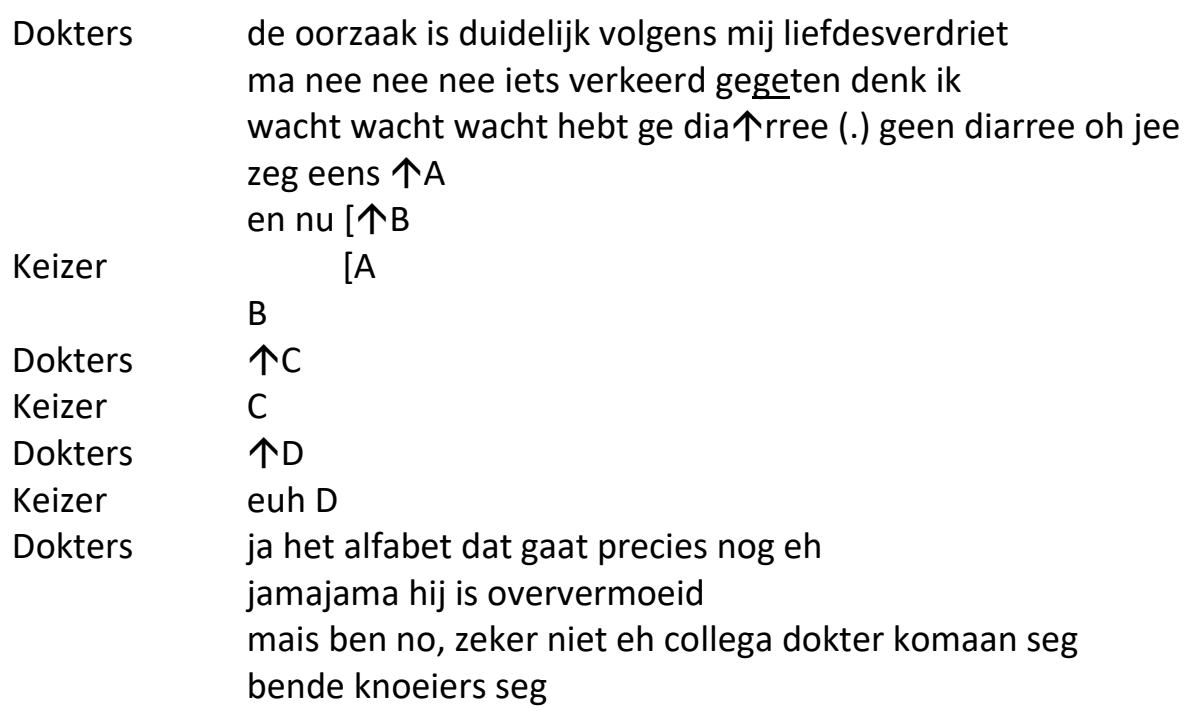

$\mathrm{Na}$ deze interactie volgt er een gevecht, waarna ze allemaal vertrekken zonder een diagnose gesteld te hebben. De dokters worden dan ook als dom gekarakteriseerd omdat ze incapabele dokters zijn die de keizer uiteindelijk niet geholpen hebben. Daarnaast hebben de dokters als kenmerk dat ze een prestigieus beroep uitoefenen. Dat beroep krijgt immers een SIOPS-score van 78, aangezien het hoort onder de groep '0061 Medical Doctors'.

Als tweede personage met een Frans accent bespreken we Passepartout uit 'De Wereld Rond in 80 Dagen', waarvan het coderingsprofiel te vinden is in tabel 13.

\begin{tabular}{|l|l|l|l|}
\hline Dimensie & Variabele & \\
\hline Solidariteit & Vriendelijk & NA & Onvriendelijk \\
\cline { 2 - 4 } & &
\end{tabular}




\begin{tabular}{|l|l|l|l|l|}
\cline { 2 - 4 } & Protagonist & Helper & Nevenpersonage & Antagonist \\
\hline \multirow{4}{*}{ Prestige } & Rijk & NA & Arm \\
\cline { 2 - 4 } & Intelligent & NA & Dom \\
\cline { 2 - 4 } & Beschaafd & NA & Onbeschaafd \\
\cline { 2 - 4 } & Prestigieus beroep & Neutraal & NA & Niet-prestigieus beroep \\
\hline \multirow{4}{*}{ Dynamisme } & Enthousiast & NA & Ongemotiveerd \\
\cline { 2 - 4 } & Stoer & NA & Laf \\
\cline { 2 - 4 } & Cool & NA & Oubollig \\
\cline { 2 - 4 } & Jong & NA & Oud \\
\hline
\end{tabular}

Tabel 13: Coderingsprofiel van de Passepartout uit 'De Wereld Rond in 80 Dagen'.

Op het vlak van solidariteit zien we dat het Frans van Passepartout een positieve solidariteit lijkt te indexeren aangezien het personage gekarakteriseerd wordt als een helper en als een vriendelijk personage in het luisterverhaal. Zijn codering als helper dankt hij aan het feit dat hij het hoofdpersonage Phileas Fogg helpt om zijn reis rond de wereld te voltooien in 80 dagen. Zijn vriendelijkheid is dan weer afgeleid uit onderstaande passage in het verhaal waarin hij zich ontfermt over Prinses Aouda. Prinses Aouda zou immers normaal geofferd worden door de Bramanen, maar Passepartout slaagt erin om haar te bevrijden door hen te overtuigen dat Brama geen vrouwenoffer wilt hebben:

(13) Passage uit 'De Wereld Rond in 80 Dagen', hoofdstuk 'Langs hier voor het foute pad', 00:28 01:02

Hogepriester heilmachtige brama:

.h zoon van vishnu

.h schepper van de kosmos en grote omgeving

.h aanvaardt u deze vrouw als $\uparrow$ offer

Passepartout en fait non

Bramanen ohh

Passepartout ik ik bedoel (.) nee

ik heb vandaag geen zin in een vrouwenoffer

meer in macarons

Bramanen $\quad$ Tuh

Passepartout laat deze vrouw met rust

breng me allemaal een stapel macarons

Daarnaast wordt Passepartout geportretteerd als een beschaafd iemand. Wanneer hij wilt vloeken zegt hij immers 'puree' in plaats van een echt scheldwoord:

(14) Passage uit 'De Wereld Rond in 80 Dagen', hoofdstuk 'Burn-, bore- and buy-out', 03:26 - 03:36

Rechter de verdachte wordt schuldig bevonden aan het verstoren van de openbare orde door het flagrant weigeren .h van het euh uitdoen van zijn schoen ja dadist

Passepartout puree gaat dat $\uparrow$ daarover 
Als laatste blijkt dat hij een neutraal beroep uitoefent qua prestige, aangezien hij als butler deel uitmaakt van de groep '05200 Steward', wat een SIOPS-score van 46 krijgt toegekend.

Ten slotte bespreken we nog Libelle Rosita uit 'De Mestkever'. Haar coderingsprofiel is te vinden in tabel 14.

\begin{tabular}{|c|c|c|c|c|c|}
\hline \multirow{3}{*}{$\begin{array}{l}\text { Dimensie } \\
\text { Solidariteit }\end{array}$} & \multicolumn{5}{|l|}{ Variabele } \\
\hline & \multicolumn{2}{|l|}{ Vriendelijk } & \multicolumn{2}{|l|}{ NA } & Onvriendelijk \\
\hline & Protagonist & Helper & \multicolumn{2}{|c|}{ Nevenpersonage } & Antagonist \\
\hline \multirow[t]{4}{*}{ Prestige } & \multicolumn{2}{|l|}{ Rijk } & \multicolumn{2}{|l|}{ NA } & Arm \\
\hline & \multicolumn{2}{|l|}{ Intelligent } & \multicolumn{2}{|l|}{ NA } & Dom \\
\hline & \multicolumn{2}{|l|}{ Beschaafd } & \multicolumn{2}{|l|}{ NA } & Onbeschaafd \\
\hline & \multicolumn{2}{|c|}{ Prestigieus beroep } & Neutraal & NA & Niet-prestigieus beroep \\
\hline \multirow[t]{4}{*}{ Dynamisme } & \multicolumn{2}{|l|}{ Enthousiast } & \multicolumn{2}{|l|}{$\mathrm{NA}$} & Ongemotiveerd \\
\hline & \multicolumn{2}{|l|}{ Stoer } & \multicolumn{2}{|l|}{ NA } & Laf \\
\hline & \multicolumn{2}{|l|}{ Cool } & \multicolumn{2}{|l|}{ NA } & Oubollig \\
\hline & \multicolumn{2}{|l|}{ Jong } & \multicolumn{2}{|l|}{ NA } & Oud \\
\hline
\end{tabular}

Tabel 14: Coderingsprofiel van Libelle Rosita uit 'De Mestkever'.

Op het vlak van prestige lijkt het Frans van Libelle Rosita een hoog prestige te indexeren, aangezien ze zowel met intelligentie als beschaafdheid geassocieerd wordt in de luisterverhalen. Haar codering als intelligent heeft ze te wijten aan haar kennis van cultuur. Zo geeft ze immers aan dat ze er veel van weet in het liedje dat ze zingt over zichzelf en dat ze walgt van mensen die er niets van weten:

(15) Passage uit 'De Mestkever', hoofdstuk 'Hoog In Haren Bol', 01:00 - 01:15

$\begin{array}{ll}\text { Libelle } & \begin{array}{l}\text { cultuur was steeds mijn gran } \\ \text { dat hoor en zie je wel } \\ \text { ik walg van al die mensen } \\ \text { ze weten rien du t[out }\end{array} \\ \text { Man } & \quad \text { seg hey } \\ \text { Libelle } & \text { excuseer een allergietje } \\ \text { Man } & \text { van rococo en van barok } \\ \text { Libelle } & \text { [((snut)) } \\ \text { Man } & \text { [ze maken mij } \\ \text { Libelle } & \text {.h fou fou }\end{array}$

Daarnaast wordt ze ook geportretteerd als een beschaafd personage. In het begeleidende boek wordt ze immers beschreven als 'een rasechte snob' die niemand vindt met een 'even verfijnde smaak' als haar. ${ }^{11}$ Ook in haar gedrag in het luisterverhaal wordt die beschaafdheid weerspiegeld. Zo spreekt ze de mestkever aan met het dure woord scarabee, en reageert ze gedegouteerd wanneer de mestkever een keutel uit een kunstinstallatie neemt om op te eten, wat er dan weer op wijst dat ze goede

\footnotetext{
${ }^{11}$ Een van onze externe beoordelaars haalt terecht aan dat je zou verwachten dat dit personage niet uitsluitend met positieve attributen wordt geassocieerd doordat ze als een 'rasechte snob' wordt neergezet waarbij het Franse accent een cruciale rol lijkt te spelen. We hebben in deze studie niet gewerkt met een 'arrogantieschaal', maar in vervolgonderzoek kan worden nagedacht op welke manier arrogantie kan worden toegevoerd; een andere optie is dat er binnen de dimensie prestige ook schalen worden verwerkt die eerder duiden op 'snobisme'.
} 
manieren belangrijk vindt. Het prestige van haar beroep als kunstkenner die een vernissage openhoudt wordt gecodeerd als neutraal. Ze behoort immers tot de groep '016 sculptors, painters, photographers and related creative artists', die een SIOPS-score van 51 toegekend krijgen. Als laatste blijkt ook dat ze gekarakteriseerd wordt als een enthousiast personage in het luisterverhaal. Wanneer ze te horen krijgt dat de mestkever graag naar haar vernissage wil komen, reageert ze enthousiast, wat blijkt uit het feit dat ze uitroept 'oh een mestkever, een echte scarabee', dat ze de naaktslak aanspoort om hem vlug binnen te laten en de verteller die zegt dat ze hem glimlachend staat op te wachten.

Uit de beschrijving van deze drie personages komt naar voren dat de drie besproken personages vrij sterk verschillen op het vlak van hun coderingsprofiel. Zo ligt de nadruk bij de dokters voornamelijk op een negatief prestige, hoewel ze ook een prestigieus beroep hebben omwille van hun job als artsen. Merk echter ook hier op dat uit de verhaallijn blijkt dat ze eerder als incapabele artsen gecodeerd moeten worden omdat ze elkaar voortdurend tegenspreken en uiteindelijk niet tot een oplossing komen. Bij Passepartout ligt de nadruk dan weer op een positieve solidariteit, en bij Libelle Rosita op een positief prestige. We kunnen dus concluderen dat het socialebetekenispotentieel van het Franse accent in de luisterverhalen vrij breed is, hoewel uit de overzichtstabel 15 wel blijkt dat het vreemde accent overwegend geassocieerd wordt met de positieve labels van de verschillende attitudedimensies. Dat het Franse accent een breed socialebetekenispotentieel heeft, is te verwachten als we de complexe geschiedenis van het Frans in Vlaanderen in het achterhoofd houden waarbij het Frans lange tijd de officiële taal alsook de taal van de elite is geweest, maar ook op heel wat tegenwind kon rekenen (Grondelaers \& Van Hout 2010).

\begin{tabular}{|c|c|c|c|c|c|}
\hline \multirow{3}{*}{$\begin{array}{l}\text { Dimensie } \\
\text { Solidariteit }\end{array}$} & \multicolumn{5}{|l|}{ Variabele } \\
\hline & \multicolumn{2}{|c|}{ Vriendelijk $(n=1)$} & \multicolumn{2}{|l|}{ NA $(n=5)$} & Onvriendelijk \\
\hline & Protagonist & Helper $(n=1)$ & \multicolumn{2}{|c|}{ Nevenpersonage $(n=5)$} & Antagonist \\
\hline \multirow[t]{4}{*}{ Prestige } & \multicolumn{2}{|l|}{ Rijk } & \multicolumn{2}{|l|}{ NA $(n=6)$} & Arm \\
\hline & \multicolumn{2}{|c|}{ Intelligent ( $n=1)$} & \multicolumn{2}{|l|}{ NA $(n=4)$} & $\operatorname{Dom}(n=1)$ \\
\hline & \multicolumn{2}{|c|}{ Beschaafd $(n=2)$} & \multicolumn{2}{|l|}{$N A(n=4)$} & Onbeschaafd \\
\hline & \multicolumn{2}{|c|}{ Prestigieus beroep $(n=1)$} & $\begin{array}{l}\text { Neutraal } \\
(n=3)\end{array}$ & $N A(n=2)$ & Niet-prestigieus beroep \\
\hline \multirow[t]{4}{*}{ Dynamisme } & \multicolumn{2}{|c|}{ Enthousiast $(n=1)$} & \multicolumn{2}{|l|}{ NA $(n=5)$} & Ongemotiveerd \\
\hline & \multicolumn{2}{|l|}{ Stoer } & \multicolumn{2}{|l|}{ NA $(n=6)$} & Laf \\
\hline & \multicolumn{2}{|l|}{ Cool } & \multicolumn{2}{|l|}{ NA $(n=6)$} & Oubollig \\
\hline & \multicolumn{2}{|l|}{ Jong } & \multicolumn{2}{|l|}{ NA $(n=6)$} & Oud \\
\hline
\end{tabular}

Tabel 15: Coderingsoverzicht voor het Frans accent.

\section{Discussie en conclusie}

Voorliggende studie vormt een nieuwe stap naar een kruisbestuiving tussen onderzoek naar de verwerving van sociale betekenis bij kinderen en de studie van taalvariatie in fictie. Aan de hand van een corpusgebaseerd onderzoek waarin het taalgebruik en de sociale eigenschappen van 260 personages uit 12 Vlaamse hoorspelen werd geanalyseerd, proberen we een antwoord te formuleren op de tot nog toe weinig bestudeerde vraag hoe die constructie van sociale betekenis via taal verloopt in fictie die bedoeld is voor een jong doelpubliek. In internationaal onderzoek bestudeerde Lippi-Green 
(1997) al of het gebruik van gemarkeerde (vreemde) accenten en sociale dialecten in Disneyfilms leidt tot discriminatie van etnische en sociale groepen. Onze studie heeft hiertoe willen bijdragen door te kijken naar de nog weinig bestudeerde Vlaamse context, maar voegde ook een bijkomende vernieuwing toe door te kijken naar taalvariatie in hoorspelen, waar, door het ontbreken van visuele ondersteuning, taal een nog prominentere rol speelt in de karakterisering van de personages.

De studie bestond uit twee grote luiken. In het eerste luik hebben we in kaart gebracht aan welk taalrepertoire de ontvangers van de hoorspelen worden blootgesteld. Hierbij hebben we niet alleen gekeken naar het aanbod tout court, maar zijn we ook nagegaan hoe divers het aanbod is en in welke mate bepaalde variëteiten of accenten al dan niet asymmetrisch aan bod komen. Een preliminaire stap binnen dit deel van de studie was de classificatie van de gebruikte variëteiten en accenten binnen het Vlaamse diaglossische continuüm. Uit dit deel van het onderzoek kunnen we, met enige voorzichtigheid omwille van de beperkte grootte van de dataset, concluderen dat de hoorspelen een brede waaier van variëteiten gebruiken die het Vlaamse diaglossische repertoire weerspiegelen: de personages hanteren voornamelijk Belgisch-Nederlandse standaardtaal en tussentaal, maar ook het Brabants en het Oost- en West-Vlaams zijn sterk vertegenwoordigd. Daarnaast komen er ook zes vreemde accenten sporadisch aan bod, alsook het Nederlands-Nederlands en Surinaams-Nederlands. De protagonisten van de verhalen spreken echter uitsluitend tussentaal en Belgisch-Nederlandse standaardtaal. Opvallend genoeg is de tussentaal wel meer vertegenwoordigd dan de standaardtaal, wat erop wijst dat tussentaal de mainstream variëteit is in Vlaamse fictie, zelfs voor kinderen. Van Hoof (2013) toonde al aan dat tussentaal (in haar termen 'een vorm van "gekuist" Vlaams') prominent aanwezig is in Vlaamse fictie voor volwassenen. Dat deze tussentaal ook zijn stempel drukt op fictie voor kinderen, is duidelijk een signaal van een emancipatie van tussentaal in Vlaanderen. Dit resultaat komt ook overeen met recent onderzoek naar kindgerichte interacties (Van De Mieroop et al. 2016), waaruit bleek dat tussentaal de referentievariëteit wordt wanneer ouders op een speelse, humoristische manier met hun (ook kleine) kinderen interageren: de Belgisch-Nederlandse standaardtaal werd voornamelijk gebruikt in directieve uitingen, maar minder in andere, meer ontspannen uitingen. Merk daarbij wel op dat deze conclusies met enige voorzichtigheid behandeld moeten worden omwille van de beperkte grootte van de dataset.

Die sociale betekenis hebben we in het tweede luik van de studie onder de loep genomen. Hierin hebben we de gebruikte variëteiten en accenten uit de hoorspelen gekoppeld aan de sociale eigenschappen van de personages waarmee ze in verband worden gebracht: we hebben met andere woorden willen begrijpen welke sociale eigenschappen door de personages worden geïndexeerd en dus ook aan welke (stereotype) koppelingen tussen taal en sociaal beeld het doelpubliek van de Heerlijke Hoorspelen wordt blootgesteld. De resultaten uit dit deel geven aan dat het Belgisch Standaardnederlands sterk geassocieerd wordt met prestige. Ook dit resultaat bevestigt voorgaand onderzoek, waaruit blijkt dat het Belgische Standaardnederlands nog steeds met een vorm van traditioneel prestige wordt geassocieerd, zelfs als de tussentaal stilaan de referentievariëteit wordt in vele contexten. Dit resultaat kwam ook naar voren in Van De Mieroop et al. (2016): dat ouders in directieve uitingen kiezen voor Standaardnederlands, betekent volgens de auteurs dat ze het de 'beste variëteit' vinden om over te dragen aan hun kinderen, hoewel ze snel overstappen naar tussentaal in ontspannen contexten en wanneer de kinderen groeien. De andere variëteiten in de hoorspelen - en met name vooral het West-Vlaams en het Frans accent - worden met een veel bredere waaier aan sociale indexen geassocieerd. Dit betekent dat kinderen bij de hoorspelen vele verschillende (soms uiteenlopende) sociale betekenissen te horen krijgen. Wellicht maken ze daardoor geen een-op-een associatie tussen het West-Vlaams of het Frans en een sociale index. Verder onderzoek moet dit echter verder uitklaren.

Anderzijds kan deze brede waaier aan indexicale waarden ook te wijten zijn aan een aantal methodologische keuzes die we hebben genomen voor deze studie, en die wellicht in toekomstig onderzoek kunnen worden verbeterd of anders belicht. Eerst en vooral hebben we voor de dimensies 
solidariteit, prestige en dynamisme gewerkt met slechts drie puntenschalen, waarvan de twee uitersten de negatieve of positieve waarde bevatte en de middelste de neutrale waarde. Dit betekent dat er weinig nuance mogelijk was in het toewijzen van de waarden, waardoor er bij twijfel meestal neutrale waarden werden toegekend. Bovendien werden de drie dimensies geoperationaliseerd aan de hand van een beperkt aantal schalen, waarvan niet alle keuzes optimaal werkten. Hoewel alle gebruikte schalen werden getest in attitude-experimenten (zie Zahn \& Hopper 1985, maar ook bijvoorbeeld Grondelaers \& Speelman 2013), leverden ze voor de toepassing in dit onderzoek niet altijd de beoogde resultaten op. Zo bleek de implementering van 'prestige' aan de hand van 'beroep' niet goed te werken voor de hoorspelen, en bleek 'enthousiasme' geen optimale schaal te zijn om het 'dynamisme' van de personages vast te leggen. In verder onderzoek dienen deze schalen verder verfijnd of gewijzigd te worden. De sociale betekenis van de accenten en variëteiten verdient in ieder geval meer aandacht in een uitgebreide studie vanuit andere methodologische invalshoeken, waarbij meer rekening wordt gehouden met de ontvanger of ook met de productie van de hoorspelen. In eerste instantie kunnen de betekenisassociaties onderzocht worden via attitude-experimenten, waarbij getest wordt in welke mate en vanaf welke leeftijd kinderen de variëteiten herkennen en welke sociale betekenis ze eraan koppelen. Niet alleen experimenteel onderzoek kan meer inzicht bieden in de sociale betekenis van de variëteiten. Een gedetailleerde discoursanalytische studie van de interacties tussen de personages zou een aantal belangrijke style-shifts tussen variëteiten en accenten kunnen verklaren. In deze studie hebben we geen rekening gehouden met intrasprekersvariatie, maar verder onderzoek naar de motivering en de betekenis van alternaties tussen bijvoorbeeld Standaardnederlands en tussentaal zouden de associatie tussen sociale betekenis en variëteit kunnen loskoppelen van de wat statige parameter 'personage' en zo een genuanceerder inzicht bieden in de manier waarop bepaalde accenten of variëteiten aan bod komen in fictie. Ook productiegericht etnografisch onderzoek kan verder inzicht verwerven in de mate waarin bepaalde regionale of vreemde accenten bewust of onbewust worden ingezet om bepaalde personages te kleuren.

Op de vraag - die Lippi-Green (1997) stelde - of de stereotypes uit deze hoorspelen leiden tot discriminatie ten opzichte van sprekers met bepaalde regionale of vreemde accenten, kan en wil deze studie geen antwoord formuleren. Wat deze studie wel kan aantonen, is dat bepaalde beelden of 'stereotypical depictions', zoals Bleichenbacher (2008: 32) het formuleerde, wel voorkomen. Naast de referentievariëteiten, zijn er een aantal stereotypische (hoewel ook erg uiteenlopende) karakteriseringen die kinderen op de een of andere manier wel kunnen oppikken en die later, bij herhalingen in andere contexten, kunnen versterkt of bestendigd worden tot een koppeling tussen de variëteit in kwestie en een bepaald stereotype.

Acknowledgments We willen graag de externe beoordelaars bedanken voor de opbouwende commentaren en onze codeurs voor hun werk.

\section{Referenties}

Agha, A. (2003). The social life of cultural value. Language and Communication 23, 231-273.

Androutsopoulos, J. (2012a). Introduction: Language and society in cinematic discourse. Multilingua $31,139-154$.

Androutsopoulos, J. (2012b). Repertoires, characters, and scenes: Sociolinguistic difference in Turkish-German comedy. Multilingua 31, 301-326.

Auer, P. (2005). Europe's sociolinguistic unity, or: A typology of European dialect/standard constellations. In: N. Delbecque, J. van der Auwera \& D. Geeraerts (red.), Perspectives on variation. Berlin/New York: Mouton De Gruyter, 7-42. 
Auer, P. (2011). Dialect vs. standard: A typology of scenarios in Europe. In: B. Kortmann \& J. Van der Auwera (red.), The languages and linguistics of Europe. A comprehensive guide. Berlin/New York: Mouton De Gruyter, 485-500.

Bednarek, M. (2010). The language of fictional television. London/New York: Continuum.

Bleichenbacher, L. (2008). Multilingualism in the movies. Hollywood characters and their language choices (Swiss Studies in English). Tübingen: Narr Francke Attempto Verla.

van Bork, G., D. Delabastita, P. Verkuijsse \& G. Vis (2012a). Antagonist. Algemeen letterkundig lexicon. <http://www.dbnl.org/tekst/dela012alge01 01/dela012alge01 01 02662.php?q= protagonist\#h|1>

van Bork, G., D. Delabastita, P. Verkuijsse \& G. Vis (2012b). Protagonist. Algemeen letterkundig lexicon. <http://www.dbnl.org/tekst/dela012alge01 01/dela012alge01 $0100728 . p h p ? q=$ antagonist\#h|1>

Bubel, C. (2008). Film audiences as overhearers. Journal of Pragmatics 40, 55-71.

De Caluwe, J. (2004). Conflicting language conceptions within the Dutch speaking part of Belgium. Trans: Internet-Zeitschrift für Kulturwissenschaften 15, 53-58.

Chevrot, J.-P., A. Nardy \& S. Barbu. (2011). Developmental dynamics of SES-related differences in children's production of obligatory and variable phonological alternations. Language Sciences 33(1), 180-191.

Coupland, N. (2007). Style: Language variation and identity (Key topics in sociolinguistics). Cambridge: Cambridge university press.

Culpeper, J. (2001). Language and characterization: People in plays and other texts. Harlow: Longman.

Delarue, S. (2014). Contrasterende (standaard)taalideologieën bij Vlaamse leerkrachten: een Gentse casestudy. Handelingen van de koninklijke maatschappij voor taal-en letterkunde en geschiedenis 67, 219-248.

Devos, M., \& R. Vandekerckhove (2005). West-Vlaams. Tielt: Lannoo.

Eckert, P. (2008). Variation and the indexical field. Journal of Sociolinguistics 12(4), 453-476.

Foulkes, P., \& G. Docherty (2005). Phonological variation in child-directed speech. Language 81(1), 177-206.

Geeraerts, D., V. Penne \& V. Vanswegenoven (2000). Thuis-taal en Familie-taal: taalgebruik in Vlaamse soaps. In: S. Gillis, J. Nuyts \& J. Taeldeman (red.), Met taal om de tuin geleid. Opstellen voor Georges De Schutter. Antwerpen: UIA, 161-170.

Ghimenton, A., J.-P. Chevrot \& J. Billiez (2013). Language choice adjustments in child production during dyadic and multiparty interactions: a quantitative approach to multilingual interactions. Linguistics 51(2), 413-438.

Ghyselen, A.-S. (2016). Verticale structuur en dynamiek van het gesproken Nederlands in Vlaanderen: een empirische studie in leper, Gent en Antwerpen. Universiteit Gent. Faculteit Letteren en Wijsbegeerte, Gent.

Ghyselen, A.-S., \& G. De Vogelaer (2018). Seeking systematicity in variation: Theoretical and methodological considerations on the "variety" concept. Frontiers in Psychology 9, 385. 
Grondelaers, S., \& P. Van Gent (2019). How "deep" is dynamism? Revisiting the evaluation of Moroccan-flavored Netherlandic. Linguistics Vanguard 5(1).

Grondelaers, S., \& R. Van Hout (2010). Is Standard Dutch with a regional accent standard or not? Evidence from native speakers' attitudes. Language Variation and Change 22, 221-239.

Grondelaers, S., R. Van Hout \& D. Speelman (2011). A perceptual typology of standard language situations in the Low Countries. In: T. Kristiansen \& N. Coupland (red.), Standard languages and language standards in a changing Europe. Oslo: Novus press, 199-222.

Grondelaers, S., R. Van Hout \& M. Steegs. (2010). Evaluating regional accent variation in Standard Dutch. Journal of Language and Social Psychology 29(1), 101-116.

Grondelaers, S., \& D. Speelman (2013). Can speaker evaluation return private attitudes towards stigmatised varieties? Evidence from emergent standardisation in Belgian Dutch. In: S. Grondelaers \& T. Kristiansen (red.), Language (de)standardisation in late modern Europe: Experimental studies. Oslo: Novus Press, 171-192.

Van Hoof, S. (2013). Feiten en fictie: een sociolinguïstische analyse van het taalgebruik in fictieseries op de Vlaamse openbare omroep (1977-2012). Universiteit Antwerpen. Faculteit Letteren en Wijsbegeerte, Antwerpen.

Van Hoof, S. (2015). Feiten en fictie: Een sociolinguïstische analyse van het taalgebruik in fictiereeksen op de Vlaamse openbare omroep (1977-2012). Gent: Academic Press.

De Houwer, A. (2003). Language variation and local elements in family discourse. Language Variation and Change 15, 329-349.

Impe, L., \& D. Speelman (2008). Vlamingen en hun (tussen)taal. Een attitudineel mixed guiseonderzoek. Handelingen van de Koninklijke Maatschappij Voor Taal- En Letterkunde En Geschiedenis 16, 129-153.

Jefferson, G. (2004). Glossary of transcript symbols with an introductions. In G. H. Lerner (red.), Conversation analysis: Studies from the first generation. Amsterdam: John Benjamins Publishing Company, 13-31.

Kerswill, P., \& A. Williams (2000). Creating a New Town koine: Children and language change in Milton Keynes. Language in Society 29(1), 65-115.

Kristiansen, T. (2009). The macro-level social meanings of late-modern Danish accents. Acta Linguistica Hafniensia 41(1), 167-192.

Lambert, W. E., R. C. Hodgson, R. Gardner \& S. Fillenbaum (1960). Evaluational reactions to spoken language. Journal of Abnormal \& Social Psychology 60(1), 44-51.

Lenz, A. (2010). Emergence of varieties through restructuring and reevaluation. In: P. Auer \& J. E. Schmidt (red.), Language and space. An international handbook of linguistic variation. Berlin/New York: De Gruyter, 295-315.

Lippi-Green, R. (1997). Teaching children to discriminate. What we learn from the Big Bad Wolf. In: English with an accent: Language, ideology and discrimination in the United States. Londen/New York: Routledge, 79-103.

Lybaert, C. (2017). A direct discourse-based approach to the study of language attitudes: The case of tussentaal in Flanders. Language Sciences 59, 93-116.

Maegaard, M. (2005). Language attitudes, norm and gender: A presentation of the method and results from a language attitude study. Acta Linguistica Hafniensia 37, 55-80. 
Mesthrie, R. (2005). Assessing representations of South African Indian English in writing: An application of variation theory. Language Variation and Change 17, 303-326.

Van De Mieroop D., E. Zenner \& S. Marzo (2016). Standard and Colloquial Belgian Dutch pronouns of address: A variationist-interactional study of child-directed speech in dinner table interactions. Folia Linguistica: Acta Societatis Linguisticae Europaeae 50(1), 31-64.

Miller, K. (2013). Acquisition of variable rules: /s/-lenition in the speech of Chilean Spanish-speaking children and their caregivers. Language Variation and Change 25(3), 311-340.

Plevoets, K. (2009). Verkavelingsvlaams als de voertaal van de verburgerlijking van Vlaanderen. Studies van de Belgische Kring Voor Linguïstiek, 4.

Propp, V. (1997). De morfologie van het toversprookje: vormleer van een genre. Utrecht: Spectrum.

Richardson, K. (2010). Television dramatic dialogue: a sociolinguistic study. New York: Oxford University Press.

Roberts, J. \& W. Labov (1995). Learning to talk Philadelphian. Language Variation and Change 7, 101122.

Ryan, E. B., \& M. A. Carranza (1975). Evaluative reactions of adolescents toward speakers of standard English and Mexican American accented English. Journal of Personality and Social Psychology 31(5), 855-863.

Ryan, E. B., H. Giles \& M. Hewstone (1988). The measurement of language attitudes. In: U. Ammon, N. Dittmar \& K. Mattheier (red.), Sociolinguistics/Soziolinguistik (Vol. 2). Berlin/New York: Mouton de Gruyter, 1068-1081.

Schmidt, J. E. (2005). Versuch zum Varietätenbegriff. In: A. Lenz \& K. Mattheier (red.), Varietäten Theorie und Empirie. Frankfurt/Main: Peter Lang, 61-74.

Silverstein, M. (2003). Indexical order and the dialectics of sociolinguistic life. Language and Communication 23(3-4), 193-229.

Smith, J., \& M. Durham (2019). Sociolinguistic variation in children's language: Acquiring community norms (Studies in language variation and change). Cambridge: Cambridge University Press.

Smith, J., M. Durham \& L. Fortune (2007). Mam, my trousers is fain doon!: Community, caregiver, and child in the acquisition of variation in a Scottish dialect. Language Variation and Change 19(1), 63-99.

Smith, J., M. Durham \& H. Richards (2013). The social and linguistic in the acquisition of sociolinguistic norms: Caregivers, children, and variation. Linguistics 51(2), 285-324.

Stokoe, E. (2008). Dispreferred actions and other interactional breaches as devices for occasioning audience laughter in television "sitcoms". Social Semiotics 18(3), 289-307.

Stuart-Smith, J. (2011). The view from the couch: Changing perspectives on the role of television in changing language ideologies and use. In: T. Kristiansen \& N. Coupland (red.), Standard languages and language standard in a changing Europe. Oslo: Novus, 223-239

Tagliamonte, S. (2014) . Situating media influence in sociolinguistic context. Journal of Sociolinguistics $18(2), 223-232$.

Treiman, D. J. (1977). Occupational prestige in comparative perspective. New York: Academic Press.

Vandekerckhove, R. (2009). Dialect loss and dialect vitality in Flanders. International Journal of the Sociology of Language 196, 73-97. 
Vandekerckhove, R., \& P. Cuvelier (2007). The perception of exclusion and proximity through the use of Standard Dutch, "tussentaal" and dialect in Flanders. In: P. Cuvelier, T. Du Plessis, M. Meeuwis \& L. Teck (red.), Multilingualism and exclusion, policy, practice and prospects. Pretoria: Van Schaik, 241-256.

De Vogelaer, G., \& M. Katerbow (2017). Acquiring sociolinguistic variation (Studies in language variation Volume 20). Amsterdam: Benjamins.

De Wachter, L., \& J. Heeren (2010). Taalvariatie in enkele 'Nederlandse' en 'Vlaams gesproken' animatiefilms. In: E. Hendrickx, K. Hendrickx, W. Martin, H. Smessaert, W. Van Belle \& J. Van der Horst (red.), Liever meer of juist minder? Over normen en variatie in taal. Gent: Academia press, 147-161.

Walker, A., C. García, Y. Cortés \& K. Campbell-Kibler (2014). Comparing social meanings across listener and speaker groups: The indexical field of Spanish /s/. Language variation and change 26(2), 169-189.

Zahn, C. J., \& R. Hopper (1985). Measuring language attitudes: The speech evaluation instrument. Journal of Language and Social Psychology 4(2), 113-123.

Žárská , L. (2019). Translation of language varieties in the Flemish dubbing of Harry Potter III. Theory and Practice in English Studies 8(1), 23-34.

\section{Auteursinformatie}

Catho Jacobs, KU Leuven, catho.jacobs@kuleuven.be

Stefania Marzo, KU Leuven, stefania.marzo@kuleuven.be

Eline Zenner, KU Leuven, eline.zenner@kuleuven.be

\section{Appendix A: Verdeling variëteiten/vreemde accenten bij sociale betekenis}

\begin{tabular}{|c|c|c|c|c|c|c|c|c|c|c|c|c|c|c|}
\hline \multicolumn{15}{|c|}{ solidariteit } \\
\hline 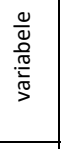 & $\begin{array}{l}\frac{0}{0} \\
\frac{\pi}{\pi} \\
3 \\
3\end{array}$ & 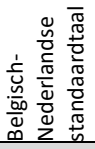 & 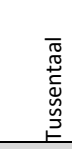 & 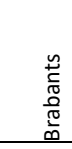 & 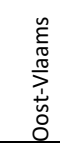 & 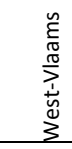 & 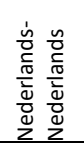 & 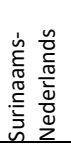 & $\begin{array}{l}\frac{n}{\tilde{c}} \\
\frac{\pi}{L}\end{array}$ & 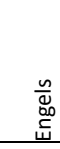 & $\begin{array}{l}\stackrel{n}{5} \\
0\end{array}$ & $\begin{array}{l}\text { con } \\
\text { on } \\
\text { ñ } \\
n\end{array}$ & 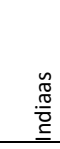 & 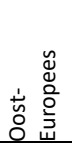 \\
\hline \multirow{8}{*}{ 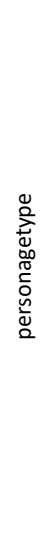 } & \multirow{2}{*}{ 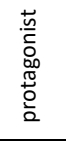 } & 3 & 10 & 0 & 0 & 0 & 0 & 0 & 0 & 0 & 0 & 0 & 0 & 0 \\
\hline & & $23,1 \%$ & $76,9 \%$ & $0,0 \%$ & $0,0 \%$ & $0,0 \%$ & $0,0 \%$ & $0,0 \%$ & $0,0 \%$ & $0,0 \%$ & $0,0 \%$ & $0,0 \%$ & $0,0 \%$ & $0,0 \%$ \\
\hline & \multirow{2}{*}{$\frac{\bar{o}}{\frac{\grave{o}}{\underline{Q}}}$} & 1 & 7 & 0 & 0 & 0 & 0 & 0 & 1 & 0 & 0 & 0 & 0 & 0 \\
\hline & & $11,1 \%$ & $77,8 \%$ & $0,0 \%$ & $0,0 \%$ & $0,0 \%-$ & $0,0 \%$ & $0,0 \%$ & $11,1 \%$ & $0,0 \%$ & $0,0 \%$ & $0,0 \%$ & $0,0 \%$ & $0,0 \%$ \\
\hline & \multirow{2}{*}{ 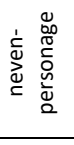 } & 43 & 42 & 17 & 2 & 13 & 3 & 1 & 5 & 4 & 3 & 2 & 2 & 0 \\
\hline & & $31,4 \%$ & $30,7 \%$ & $12,4 \%$ & $1,5 \%$ & $9,5 \%$ & $2,2 \%$ & $0,7 \%$ & $3,6 \%$ & $2,9 \%$ & $2,2 \%$ & $1,5 \%$ & $1,5 \%$ & $0,0 \%$ \\
\hline & \multirow{2}{*}{ 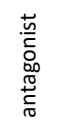 } & 3 & 3 & 0 & 0 & 0 & 2 & 0 & 0 & 0 & 1 & 0 & 0 & 1 \\
\hline & & $30,0 \%$ & $30,0 \%$ & $0,0 \%$ & $0,0 \%$ & $0,0 \%$ & $20,0 \%$ & $0,0 \%$ & $0,0 \%$ & $0,0 \%$ & $10,0 \%$ & $0,0 \%$ & $0,0 \%$ & $\begin{array}{r}10,0 \\
\% \\
\end{array}$ \\
\hline 密 & 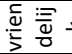 & 5 & 15 & 0 & 0 & 1 & 0 & 0 & 1 & 0 & 1 & 0 & 2 & 0 \\
\hline
\end{tabular}




\begin{tabular}{|c|c|c|c|c|c|c|c|c|c|c|c|c|c|c|}
\hline & & $20,0 \%$ & $60,0 \%$ & $0,0 \%$ & $0,0 \%$ & $4,0 \%$ & $0,0 \%$ & $0,0 \%$ & $4,0 \%$ & $0,0 \%$ & $4,0 \%$ & $0,0 \%$ & $8,0 \%$ & $0,0 \%$ \\
\hline & \multirow{2}{*}{$\Sigma$} & 41 & 36 & 11 & 2 & 12 & 4 & 1 & 5 & 3 & 3 & 0 & 0 & 0 \\
\hline & & $34,7 \%$ & $30,5 \%$ & $9,3 \%$ & $1,7 \%$ & $10,2 \%$ & $3,4 \%$ & $0,8 \%$ & $4,2 \%$ & $2,5 \%$ & $2,5 \%$ & $0,0 \%$ & $0,0 \%$ & $0,0 \%$ \\
\hline & \multirow{2}{*}{ 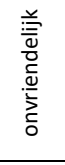 } & 4 & 11 & 6 & 0 & 0 & 1 & 0 & 0 & 1 & 0 & 2 & 0 & 1 \\
\hline & & $15,4 \%$ & $42,3 \%$ & $23,1 \%$ & $0,0 \%$ & $0,0 \%$ & $3,8 \%$ & $0,0 \%$ & $0,0 \%$ & $3,8 \%$ & $0,0 \%$ & $7,7 \%$ & $0,0 \%$ & $3,8 \%$ \\
\hline \multicolumn{15}{|c|}{ prestige } \\
\hline $\begin{array}{l}\frac{0}{0} \\
\frac{0}{\pi} \\
\frac{\pi}{\frac{\pi}{\pi}} \\
\frac{\pi}{>}\end{array}$ & $\begin{array}{l}\frac{\pi}{0} \\
\frac{0}{\pi} \\
\frac{\pi}{3} \\
3\end{array}$ & 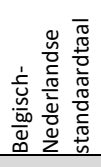 & 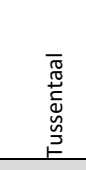 & $\begin{array}{l}\frac{n}{2} \\
\frac{\pi}{\pi} \\
0 \\
\frac{0}{\pi} \\
0\end{array}$ & 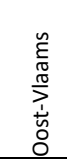 & 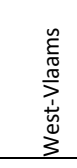 & 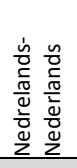 & 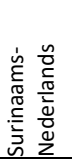 & 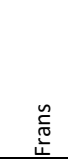 & $\begin{array}{l}\frac{\omega}{\Xi} \\
\stackrel{0}{\omega} \\
\stackrel{\omega}{W}\end{array}$ & $\stackrel{\frac{n}{3}}{0}$ & $\begin{array}{l}n \\
\frac{n}{\pi} \\
\pi \\
0 \\
0 \\
0\end{array}$ & 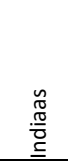 & 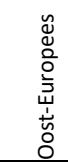 \\
\hline \multirow{6}{*}{$\begin{array}{l}\frac{\varepsilon}{0} \\
\frac{0}{0} \\
\frac{\sigma}{2}\end{array}$} & \multirow{2}{*}{ 鸢 } & 4 & 1 & 1 & 0 & 0 & 1 & 0 & 0 & 1 & 0 & 1 & 0 & 0 \\
\hline & & $44,4 \%$ & $11,1 \%$ & $11,1 \%$ & $0,0 \%$ & $0,0 \%$ & $11,1 \%$ & $0,0 \%$ & $0,0 \%$ & $11,1 \%$ & $0,0 \%$ & $11,1 \%$ & $0,0 \%$ & $0,0 \%$ \\
\hline & \multirow{2}{*}{ 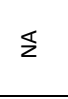 } & 46 & 54 & 16 & 2 & 12 & 4 & 1 & 6 & 3 & 4 & 1 & 2 & 1 \\
\hline & & $30,3 \%$ & $35,5 \%$ & $10,5 \%$ & $1,3 \%$ & $7,9 \%$ & $2,6 \%$ & $0,7 \%$ & $3,9 \%$ & $2,0 \%$ & $2,6 \%$ & $0,7 \%$ & $1,3 \%$ & $0,7 \%$ \\
\hline & \multirow{2}{*}{$\frac{\xi}{\sigma}$} & 0 & 7 & 0 & 0 & 1 & 0 & 0 & 0 & 0 & 0 & 0 & 0 & 0 \\
\hline & & $0,0 \%$ & $87,5 \%$ & $0,0 \%$ & $0,0 \%$ & $12,5 \%$ & $0,0 \%$ & $0,0 \%$ & $0,0 \%$ & $0,0 \%$ & $0,0 \%$ & $0,0 \%$ & $0,0 \%$ & $0,0 \%$ \\
\hline \multirow{6}{*}{ 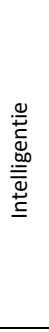 } & \multirow{2}{*}{ 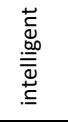 } & 6 & 4 & 0 & 0 & 0 & 2 & 0 & 1 & 2 & 1 & 0 & 0 & 0 \\
\hline & & $37,5 \%$ & $25,0 \%$ & $0,0 \%$ & $0,0 \%$ & $0,0 \%$ & $12,5 \%$ & $0,0 \%$ & $6,3 \%$ & $12,5 \%$ & $6,3 \%$ & $0,0 \%$ & $0,0 \%$ & $0,0 \%$ \\
\hline & \multirow{2}{*}{$\Sigma$} & 42 & 53 & 14 & 1 & 9 & 3 & 1 & 4 & 2 & 2 & 2 & 2 & 1 \\
\hline & & $30,9 \%$ & $39,0 \%$ & $10,3 \%$ & $0,7 \%$ & $6,6 \%$ & $2,2 \%$ & $0,7 \%$ & $2,9 \%$ & $1,5 \%$ & $1,5 \%$ & $1,5 \%$ & $1,5 \%$ & $0,7 \%$ \\
\hline & \multirow{2}{*}{$\begin{array}{l}\varepsilon \\
\text { 음 }\end{array}$} & 2 & 5 & 3 & 1 & 4 & 0 & 0 & 1 & 0 & 1 & 0 & 0 & 0 \\
\hline & & $11,8 \%$ & $29,4 \%$ & $17,6 \%$ & $5,9 \%$ & $23,5 \%$ & $0,0 \%$ & $0,0 \%$ & $5,9 \%$ & $0,0 \%$ & $5,9 \%$ & $0,0 \%$ & $0,0 \%$ & $0,0 \%$ \\
\hline \multirow{6}{*}{ 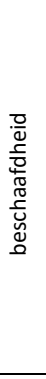 } & \multirow{2}{*}{ 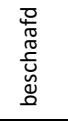 } & 12 & 2 & 1 & 0 & 1 & 0 & 0 & 2 & 2 & 1 & 0 & 0 & 0 \\
\hline & & $57,1 \%$ & $9,5 \%$ & $4,8 \%$ & $0,0 \%$ & $4,8 \%$ & $0,0 \%$ & $0,0 \%$ & $9,5 \%$ & $9,5 \%$ & $4,8 \%$ & $0,0 \%$ & $0,0 \%$ & $0,0 \%$ \\
\hline & \multirow{2}{*}{ 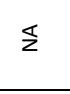 } & 35 & 52 & 12 & 0 & 9 & 4 & 1 & 4 & 2 & 3 & 2 & 2 & 0 \\
\hline & & $27,8 \%$ & $41,3 \%$ & $9,5 \%$ & $0,0 \%$ & $7,1 \%$ & $3,2 \%$ & $0,8 \%$ & $3,2 \%$ & $1,6 \%$ & $2,4 \%$ & $1,6 \%$ & $1,6 \%$ & $0,0 \%$ \\
\hline & 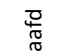 & 3 & 8 & 4 & 2 & 3 & 1 & 0 & 0 & 0 & 0 & 0 & 0 & 1 \\
\hline & โิ & $13,6 \%$ & $36,4 \%$ & $18,2 \%$ & $9,1 \%$ & $13,6 \%$ & $4,5 \%$ & $0,0 \%$ & $0,0 \%$ & $0,0 \%$ & $0,0 \%$ & $0,0 \%$ & $0,0 \%$ & $4,5 \%$ \\
\hline \multirow{8}{*}{ 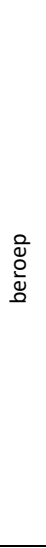 } & \multirow{2}{*}{ 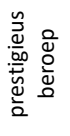 } & 7 & 4 & 2 & 0 & 2 & 0 & 0 & 1 & 3 & 1 & 0 & 0 & 0 \\
\hline & & 0,35 & 0,2 & 0,1 & 0 & 0,1 & 0 & 0 & 0,05 & 0,15 & 0,05 & 0 & 0 & 0 \\
\hline & \multirow{2}{*}{ 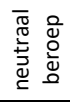 } & 18 & 18 & 5 & 0 & 5 & 1 & 1 & 3 & 0 & 3 & 2 & 2 & 0 \\
\hline & & $31,0 \%$ & $31,0 \%$ & $8,6 \%$ & $0,0 \%$ & $8,6 \%$ & $1,7 \%$ & $1,7 \%$ & $5,2 \%$ & $0,0 \%$ & $5,2 \%$ & $3,4 \%$ & $3,4 \%$ & $0,0 \%$ \\
\hline & \multirow{2}{*}{$\S$} & 17 & 32 & 7 & 2 & 5 & 3 & 0 & 2 & 1 & 0 & 0 & 0 & 1 \\
\hline & & $24,3 \%$ & $45,7 \%$ & $10,0 \%$ & $2,9 \%$ & $7,1 \%$ & $4,3 \%$ & $0,0 \%$ & $2,9 \%$ & $1,4 \%$ & $0,0 \%$ & $0,0 \%$ & $0,0 \%$ & $1,4 \%$ \\
\hline & \multirow{2}{*}{ 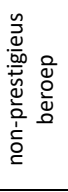 } & 8 & 8 & 3 & 0 & 1 & 1 & 0 & 0 & 0 & 0 & 0 & 0 & 0 \\
\hline & & $38,1 \%$ & $38,1 \%$ & $14,3 \%$ & $0,0 \%$ & $4,8 \%$ & $4,8 \%$ & $0,0 \%$ & $0,0 \%$ & $0,0 \%$ & $0,0 \%$ & $0,0 \%$ & $0,0 \%$ & $0,0 \%$ \\
\hline \multicolumn{15}{|c|}{ dynamisme } \\
\hline $\begin{array}{l}\frac{0}{0} \\
\frac{0}{.0} \\
\frac{\pi}{\pi} \\
\frac{\pi}{>}\end{array}$ & $\begin{array}{l}\frac{\pi}{0} \\
\frac{0}{5} \\
\frac{\pi}{3} \\
3\end{array}$ & 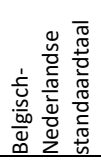 & 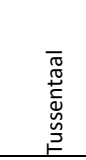 & 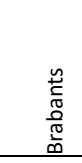 & 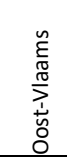 & 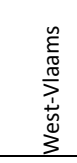 & 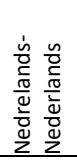 & 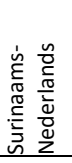 & 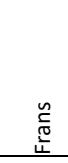 & 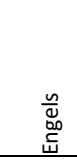 & 芳 & $\begin{array}{l}\frac{n}{\pi} \\
\pi \\
\pi \\
0 \\
n\end{array}$ & $\begin{array}{l}\stackrel{n}{\pi} \\
\stackrel{\pi}{\frac{\pi}{0}} \\
\underline{\underline{\Xi}}\end{array}$ & 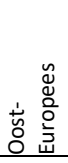 \\
\hline
\end{tabular}




\begin{tabular}{|c|c|c|c|c|c|c|c|c|c|c|c|c|c|c|}
\hline \multirow{6}{*}{ 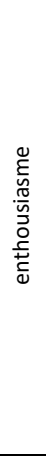 } & \multirow{2}{*}{ 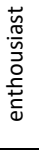 } & 5 & 18 & 4 & 1 & 3 & 0 & 1 & 1 & 2 & 0 & 0 & 0 & 0 \\
\hline & & $14,3 \%$ & $51,4 \%$ & $11,4 \%$ & $2,9 \%$ & $8,6 \%$ & $0,0 \%$ & $2,9 \%$ & $2,9 \%$ & $5,7 \%$ & $0,0 \%$ & $0,0 \%$ & $0,0 \%$ & $0,0 \%$ \\
\hline & \multirow{2}{*}{$\Sigma$} & 42 & 40 & 13 & 1 & 9 & 5 & 0 & 5 & 2 & 4 & 2 & 2 & 1 \\
\hline & & $33,3 \%$ & $31,7 \%$ & $10,3 \%$ & $0,8 \%$ & $7,1 \%$ & $4,0 \%$ & $0,0 \%$ & $4,0 \%$ & $1,6 \%$ & $3,2 \%$ & $1,6 \%$ & $1,6 \%$ & $0,8 \%$ \\
\hline & \multirow{2}{*}{ 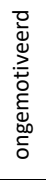 } & 3 & 4 & 0 & 0 & 1 & 0 & 0 & 0 & 0 & 0 & 0 & 0 & 0 \\
\hline & & $37,5 \%$ & $50,0 \%$ & $0,0 \%$ & $0,0 \%$ & $12,5 \%$ & $0,0 \%$ & $0,0 \%$ & $0,0 \%$ & $0,0 \%$ & $0,0 \%$ & $0,0 \%$ & $0,0 \%$ & $0,0 \%$ \\
\hline \multirow{6}{*}{$\underline{\Psi}$} & \multirow{2}{*}{ 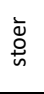 } & 3 & 7 & 0 & 1 & 0 & 0 & 0 & 0 & 0 & 1 & 1 & 0 & 0 \\
\hline & & $23,1 \%$ & $53,8 \%$ & $0,0 \%$ & $7,7 \%$ & $0,0 \%$ & $0,0 \%$ & $0,0 \%$ & $0,0 \%$ & $0,0 \%$ & $7,7 \%$ & $7,7 \%$ & $0,0 \%$ & $0,0 \%$ \\
\hline & \multirow{2}{*}{$\Sigma$} & 47 & 51 & 17 & 1 & 13 & 5 & 1 & 6 & 4 & 3 & 1 & 2 & 1 \\
\hline & & $30,9 \%$ & $33,6 \%$ & $11,2 \%$ & $0,7 \%$ & $8,6 \%$ & $3,3 \%$ & $0,7 \%$ & $3,9 \%$ & $2,6 \%$ & $2,0 \%$ & $0,7 \%$ & $1,3 \%$ & $0,7 \%$ \\
\hline & \multirow{2}{*}{ 芴 } & 0 & 4 & 0 & 0 & 0 & 0 & 0 & 0 & 0 & 0 & 0 & 0 & 0 \\
\hline & & $0,0 \%$ & $\begin{array}{r}100,0 \\
\% \\
\end{array}$ & $0,0 \%$ & $0,0 \%$ & $0,0 \%$ & $0,0 \%$ & $0,0 \%$ & $0,0 \%$ & $0,0 \%$ & $0,0 \%$ & $0,0 \%$ & $0,0 \%$ & $0,0 \%$ \\
\hline \multirow{6}{*}{$\begin{array}{l}\overline{0} \\
0\end{array}$} & \multirow{2}{*}{$\overline{8}$} & 3 & 3 & 1 & 0 & 0 & 0 & 1 & 0 & 0 & 0 & 0 & 0 & 0 \\
\hline & & $37,5 \%$ & $37,5 \%$ & $12,5 \%$ & $0,0 \%$ & $0,0 \%$ & $0,0 \%$ & $12,5 \%$ & $0,0 \%$ & $0,0 \%$ & $0,0 \%$ & $0,0 \%$ & $0,0 \%$ & $0,0 \%$ \\
\hline & \multirow{2}{*}{$\Sigma$} & 47 & 59 & 15 & 2 & 13 & 5 & 0 & 6 & 4 & 4 & 2 & 2 & 1 \\
\hline & & $29,4 \%$ & $36,9 \%$ & $9,4 \%$ & $1,3 \%$ & $8,1 \%$ & $3,1 \%$ & $0,0 \%$ & $3,8 \%$ & $2,5 \%$ & $2,5 \%$ & $1,3 \%$ & $1,3 \%$ & $0,6 \%$ \\
\hline & \multirow{2}{*}{$\begin{array}{l}\frac{.00}{\grave{\overline{0}}} \\
\frac{0}{3} \\
0\end{array}$} & 0 & 0 & 1 & 0 & 0 & 0 & 0 & 0 & 0 & 0 & 0 & 0 & 0 \\
\hline & & 0 & 0 & 1 & 0 & 0 & 0 & 0 & 0 & 0 & 0 & 0 & 0 & 0 \\
\hline \multirow{6}{*}{ 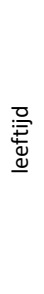 } & \multirow{2}{*}{ 음 } & 7 & 23 & 1 & 0 & 1 & 0 & 0 & 0 & 0 & 0 & 0 & 0 & 0 \\
\hline & & $21,9 \%$ & $71,9 \%$ & $3,1 \%$ & $0,0 \%$ & $3,1 \%$ & $0,0 \%$ & $0,0 \%$ & $0,0 \%$ & $0,0 \%$ & $0,0 \%$ & $0,0 \%$ & $0,0 \%$ & $0,0 \%$ \\
\hline & \multirow{2}{*}{$\Sigma$} & 33 & 33 & 13 & 2 & 11 & 3 & 1 & 6 & 4 & 4 & 1 & 2 & 1 \\
\hline & & $28,9 \%$ & $28,9 \%$ & $11,4 \%$ & $1,8 \%$ & $9,6 \%$ & $2,6 \%$ & $0,9 \%$ & $5,3 \%$ & $3,5 \%$ & $3,5 \%$ & $0,9 \%$ & $1,8 \%$ & $0,9 \%$ \\
\hline & \multirow{2}{*}{ 음 } & 10 & 6 & 3 & 0 & 1 & 2 & 0 & 0 & 0 & 0 & 1 & 0 & 0 \\
\hline & & $43,5 \%$ & $26,1 \%$ & $13,0 \%$ & $0,0 \%$ & $4,3 \%$ & $8,7 \%$ & $0,0 \%$ & $0,0 \%$ & $0,0 \%$ & $0,0 \%$ & $4,3 \%$ & $0,0 \%$ & $0,0 \%$ \\
\hline
\end{tabular}

